\title{
Extent and scale of local adaptation in salmonid fishes: review and meta-analysis
}

\author{
DJ Fraser ${ }^{1}$, LK Weir ${ }^{2}$, L Bernatchez ${ }^{3}$, MM Hansen $^{4}$ and EB Taylor ${ }^{5}$ \\ ${ }^{1}$ Department of Biology, Concordia University, Montreal, Québec, Canada; ${ }^{2}$ Department of Biological Sciences, Simon Fraser University, \\ Burnaby, British Columbia, Canada; ${ }^{3}$ IBIS (Institut de Biologie Intégrative et des Systèmes), Université Laval, Québec city, Québec, \\ Canada; ${ }^{4}$ Department of Biological Sciences, Aarhus University, Aarhus C, Denmark and ${ }^{5}$ Department of Zoology, University \\ of British Columbia, Vancouver, British Columbia, Canada
}

\begin{abstract}
What is the extent and scale of local adaptation (LA)? How quickly does LA arise? And what is its underlying molecular basis? Our review and meta-analysis on salmonid fishes estimates the frequency of LA to be $\sim 55-70 \%$, with local populations having a 1.2 times average fitness advantage relative to foreign populations or to their performance in new environments. Salmonid LA is evident at a variety of spatial scales (for example, few $\mathrm{km}$ to $>1000 \mathrm{~km}$ ) and can manifest itself quickly (6-30 generations). As the geographic scale between populations increases, LA is generally more frequent and stronger. Yet the extent of LA in salmonids does not appear to differ from that in other assessed taxa. Moreover, the frequency with which foreign salmonid populations outperform local populations ( $\sim 23-$ $35 \%$ ) suggests that drift, gene flow and plasticity often limit or mediate LA. The relatively few studies based on candidate
\end{abstract}

gene and genomewide analyses have identified footprints of selection at both small and large geographical scales, likely reflecting the specific functional properties of loci and the associated selection regimes (for example, local niche partitioning, pathogens, parasites, photoperiodicity and seasonal timing). The molecular basis of LA in salmonids is still largely unknown, but differential expression at the same few genes is implicated in the convergent evolution of certain phenotypes. Collectively, future research will benefit from an integration of classical and molecular approaches to understand: (i) species differences and how they originate, (ii) variation in adaptation across scales, life stages, population sizes and environmental gradients, and (iii) evolutionary responses to human activities.

Heredity (2011) 106, 404-420; doi:10.1038/hdy.2010.167; published online 12 January 2011

Keywords: local adaptation; salmon; genomics; genetic differentiation; selection; conservation

\section{Introduction}

Environmental heterogeneity across the geographic range of species should exert local selective pressures that act to maximize individual fitness within specific environments. This process is known as local adaptation (LA) wherein individuals of a local population exhibit higher fitness in their local environment compared with individuals from a different population and environment (Box 1; Kawecki and Ebert, 2004). The state of becoming locally adapted, however, is not an inevitable outcome even where different selective pressures operate. Selection can be counteracted by gene flow or rendered less efficient by genetic drift (Wright, 1931), frequent extinction and recolonization may impede the process towards LA (Levins, 1968), and the intensity or direction of selection in relation to environmental heterogeneity may vary temporally, favouring generalist genotypes and/or phenotypic plasticity over LA per se (Bradshaw, 1965). Consequently, conditions predicted to result in LA include: low gene flow (from low dispersal or high habitat fidelity), greater spatial than temporal variation

Correspondence: Dr DJ Fraser, Department of Biology, Concordia University, 7141 Sherbrooke St West, Montreal, Quebec, Canada H4B 1R6. E-mail:djfraser@alcor.concordia.ca

Received 7 May 2010; revised 15 October 2010; accepted 24 November 2010; published online 12 January 2011 in selection, small or negligible fluctuations in habitat quality and/or where costs or constraints to plasticity exist (Kawecki and Ebert, 2004).

Consideration of LA has a long-standing tradition in well-studied salmonid fishes, which include salmon, trout, charr, whitefishes and graylings (Ricker, 1972; Taylor, 1991; Adkison, 1995; Garcia de Leaniz et al., 2007). Salmonids are highly structured spatially because of their natal homing and frequently low dispersal between habitat patches (Quinn, 2005), trait differentiation among populations is often associated with local environmental features (Taylor, 1991), most phenotypic traits have a heritable component (Carlson and Seamons, 2008), and trait differences can translate into individual fitness differences (Garcia de Leaniz et al., 2007). These observations, along with the failure of many historical transplants of salmonids within their native ranges (Withler, 1982; Federenko and Shepherd, 1986) have resulted in a chief paradigm of salmonid biology that populations are adapted to their local environments. Despite this paradigm, the extent and scale of salmonid LA remains poorly characterized, as does its molecular basis. Furthermore, the vast majority of evidence in support of the salmonid LA paradigm is only circumstantial and indirect.

Understanding what drives the extent and scale of LA in salmonids is important for several reasons. The study 
Box 1 Criteria for demonstrating local adaptation

(a) Populations must exhibit different fitness across different environments.

(b) A population must exhibit higher fitness in its 'local' environment (or under experimental conditions resembling those of the 'local' environment) compared with 'foreign' populations in the same environment (the 'local vs foreign' criterion). There has been some controversy regarding whether LA should also be defined as individuals exhibit higher fitness in their own environment compared with a different environment ('home vs away'). Ideally, both 'local vs foreign' and 'home vs away' criteria should be fulfilled to provide evidence for local adaptation. However, we concur with Kawecki and Ebert, 2004 that 'local vs foreign' should be the main criterion, as it directly addresses the issue of divergent selection. In contrast, the 'home vs away' criterion could be fulfilled if population A performs better in environment $\mathrm{A}$ than in environment $\mathrm{B}$, and population $\mathrm{B}$ performs better in environment $\mathrm{B}$ than in environment $\mathrm{A}$, even if population $\mathrm{A}$ performs better than population B in both environments, thereby not strictly fulfilling a criterion of LA.

(c) It must be demonstrated that fitness differences among populations have a heritable basis: maternal effects, phenotypic plasticity, previous experience effects and experimental artifacts must be ruled out or controlled for. In the case of applying molecular tools, population differences at the loci or genes in question must also be shown to be because of selection as opposed to genetic drift. This can be done either by specific tests for selection for example, (Storz, 2005), or an extrinsic hypothesis that states a mechanism between variation at traits and genes, and local environmental variables (Joost et al., 2007). Genome scans should include a statement of a mechanism between loci subject to selection and environmental variables in order to rule out type 1 error. Parallelism in patterns should be tested to more firmly assess the role of selection acting on outlier loci.

of extensive geographic variation within salmonids can be exploited to better understand LA's significance as a fundamental element of evolutionary change (Hendry and Stearns, 2004), including speciation (Behnke, 1972; Bernatchez et al., 2010). In addition, understanding LA is central to determining how quickly, and to what extent, particular salmonid populations will respond to habitat alterations (Haugen et al., 2008), climate change (Crozier et al., 2008), fisheries- or farming-induced evolution (Hutchings and Fraser, 2008) and interactions with hatchery- or captive-reared counterparts (Araki et al., 2008; Fraser, 2008). Quantifying the extent and scale of LA is also increasingly important to the definition and application of conservation units within species for legal protection, including 'distinct population segments' under the US Endangered Species Act (Waples, 1991) and 'designatable units' under Canada's Species at Risk Act (Green, 2005). Even in the absence of formal legal recognition of intraspecific conservation units, a consideration of the scale and extent of LA can be important in proactive conservation prioritization (Taylor et al., 2011) or in restoration programs (Ricker, 1972; Hendry et al., 2003). Indeed, the failure of many restoration programs within the native ranges of Pacific salmon has been suggested to partly result from inadequate adaptive 'matching' of translocated populations to their new environments (Allendorf and Waples, 1996). Functional gene-associated molecular markers are one example of how locally adapted populations might be identified and used in restoration or even aquaculture development projects (Bonin and Bernatchez, 2009).

Many approaches and tools can be used to study adaptation (reviewed extensively in Endler, 1986; Reznick and Travis, 1996; Kawecki and Ebert, 2004; see also Garcia de Leaniz et al., 2007 for an excellent discussion relating to salmonids). Owing to their different properties, however, they do not all yield the same kind of information on LA, nor are they necessarily equally capable of demonstrating the existence of LA (Endler, 1986; Garcia de Leaniz et al., 2007). Namely, reciprocal transplant experiments, translocations and common-garden field experiments offer the most tractable means to demonstrate conclusively the existence of LA. In particular, the former two can be used to determine the magnitude by which fitness varies across populations and environments. Yet interpretations of LA with these approaches can still be challenging if study animals incur post-release stress or if maternal effects are not accounted for (Kawecki and Ebert, 2004). It can also be difficult to decipher the exact or potential selective agents, traits or genes implicated in LA with these approaches, in contrast to studies at the phenotypic or molecular level (Garcia de Leaniz et al., 2007). These latter studies may also reveal information on the likely scale or speed of LA if they are done in concert with a consideration of local environmental features, common-garden laboratory experiments, and/or after translocations or known environmental perturbations.

What then, do existing empirical studies suggest about the extent and scale of LA in salmonids? A first objective of this review is to address this question quantitatively using meta-analysis. We then summarise empirical studies that shed light on two other important elements of salmonid LA: its (i) potential speed and (ii) molecular basis. For (i), we found only one study in the wild that included a measure of fitness (Unwin et al., 2003), so we also review relevant literature on the rate of phenotypic and molecular change in salmonids following known environmental perturbations and translocations. For (ii), no studies on salmonids, as yet, have translated variation at the molecular level to fitness differences among populations that fulfilled LA criteria. We thus consider what molecular approaches have revealed about the potential selective agents or specific traits implicated in putative salmonid LA, the likely extent or scale of LA and the molecular basis of LA. The main impetus for our objectives was to integrate information on LA collected over several decades on salmonids using a variety of approaches and tools. The role of phenotypic plasticity in mediating salmonid LA, another important consideration, is considered by Hutchings (2011).

\section{The extent and scale of LA}

\section{Meta-analysis and quantitative survey of fitness data}

We reviewed the primary and secondary literature for available data on the extent and scale of LA in salmonids. Our meta-analysis considered two LA criteria, 'local vs foreign' and 'home vs away' (Box 1). For these criteria, we found a total of 15 and 11 studies, respectively, conducted on five species and at one or multiple life stages, for a total of 48 and 45 interpopulation compar- 
Table 1 Summary of salmonid fitness data related to the 'local vs foreign' criterion of local adaptation

\begin{tabular}{|c|c|c|c|c|c|c|c|}
\hline \multirow[t]{2}{*}{ Species } & \multirow[t]{2}{*}{ Fitness measure } & \multirow[t]{2}{*}{ Life stage } & \multirow[t]{2}{*}{ Comp $^{\mathrm{a}}$} & \multicolumn{3}{|c|}{ Fitness, local vs foreign } & \multirow[t]{2}{*}{ Reference } \\
\hline & & & & $>$ & $=$ & $<$ & \\
\hline \multicolumn{8}{|c|}{ Studies in the wild } \\
\hline AS & Survival (adult recovery rate) & Egg to adult return & 2 & 2 & - & - & Garcia de Leaniz et al., 1989 \\
\hline AS & Survival & Fertilized egg to hatch & 2 & 1 & 1 & - & Donaghy and Verspoor, 1997 \\
\hline AS & Survival (adult recovery rate) & Eyed egg to adult return & 1 & 1 & - & - & McGinnity et al., 2004 \\
\hline AS & Survival (recapture rates) & Fry to age $0+$ in freshwater & 6 & - & 6 & - & Houde et al., 2010 \\
\hline CS & Survival (adult recovery rate) & Fry to adult return & 1 & 1 & - & - & Brannon and Hershberger, 1984 \\
\hline CS & Survival (adult recovery rate) & Fry (6 months) to adult return & 2 & 2 & - & - & Unwin et al., 2003 \\
\hline CS & Survival (adult recovery rate) & Early juvenile to adult return & 2 & 1 & - & 1 & Bagatell et al., 1981a \\
\hline CS & Survival (adult recovery rate) & Early juvenile to adult return & 2 & 1 & - & 1 & Fuss et al., 1981 \\
\hline $\mathrm{CO}$ & Survival (adult recovery rate) & Early juvenile to adult return & $5^{\mathrm{b}}$ & 4 & - & 1 & Bagatell et al., 1980 \\
\hline $\mathrm{CO}$ & Survival (adult recovery rate) & Early juvenile to adult return & $6^{\mathrm{b}}$ & 2 & - & 4 & Bagatell et al., 1981b \\
\hline $\mathrm{CO}$ & Survival (adult recovery rate) & Early juvenile to adult return & $4^{\mathrm{b}}$ & 1 & 2 & 1 & Bagatell et al., 1981c \\
\hline $\mathrm{CO}$ & Survival (adult recovery rate) & Early juvenile to adult return & $5^{\mathrm{b}}$ & 2 & 1 & 2 & Fuss and Rasch, 1981 \\
\hline $\mathrm{CO}$ & Survival (adult recovery rate) & Smolt to adult return & $4^{\mathrm{b}}$ & 1 & 3 & - & Dann and Smoker, 2010 \\
\hline MS & Survival (adult recovery rate) & Smolt to adult return & $4^{\mathrm{b}}$ & 4 & - & - & Mayama et al., 1989 \\
\hline $\mathrm{BT}$ & Survival (tag return rate) & Smolt to adult & 2 & 1 & - & 1 & Bartel et al., 2001 \\
\hline \multicolumn{8}{|c|}{ Laboratory studies } \\
\hline AS & Survival $(\mathrm{pH})$ & Alevin to 69 days post-hatch & 2 & 1 & 1 & - & Fraser et al., 2008 \\
\hline CS & Survival (temperature) & Fertilized egg to emergence & 4 & 1 & 3 & - & Beacham and Murray, 1989 \\
\hline $\mathrm{CO}$ & Survival (salinity tolerance) & Juvenile & 1 & 1 & - & - & Kreeger, 1995 \\
\hline CS & Survival (water chemistry) & Eyed egg to yolk absorption & 2 & - & 2 & - & Evans et al., 2010 \\
\hline $\mathrm{CO}$ & Survival (pathogen resistance) & Juvenile & 2 & 2 & - & - & Hemmingsen et al., 1986 \\
\hline $\mathrm{CO}$ & Survival (pathogen resistance) & Juvenile & 1 & 1 & - & - & Bower et al., 1995 \\
\hline SS & Survival (temperature) & Fertilized egg to emergence & 2 & 1 & 1 & - & Beacham and Murray, 1989 \\
\hline SS & Survival (pathogen resistance) & Juvenile & 1 & 1 & - & - & Bower et al., 1995 \\
\hline SS & Survival (temperature) & Fertilized eggs to emergence & 2 & - & 2 & - & Hendry et al., 1998 \\
\hline $\mathrm{CH}$ & Survival (temperature) & Fertilized eggs to emergence & 4 & 1 & 2 & 1 & Beacham and Murray, 1986 \\
\hline RT & Survival (pathogen resistance) & Juvenile & 1 & 1 & - & - & Buchanan et al., 1983 \\
\hline EG & Survival (temperature) & Hatch to emergence & 6 & 6 & - & - & Haugen and Vollestad, 2000 \\
\hline
\end{tabular}

Abbreviations: AC, Arctic charr (Salvelinus alpinus); AS, Atlantic salmon (Salmo salar); BC, Brook charr (Salvelinus fontinalis); BT, Brown trout (Salmo trutta); CH, Chum salmon (Oncorhynchus keta); CO, Coho salmon (Oncorhynchus kisutch); CS, Chinook salmon (Oncorhynchus tshawtyscha); EG, European grayling (Thymallus thymallus); LC, Lake charr (Salvelinus namaycush); LW, Lake whitefish (Coregonus clupeaformis); MS, Masou salmon (Oncorhynchus masou); PS, Pacific salmon, general (Oncorhynchus spp.); RT, Rainbow trout (Oncorhynchus mykiss); SS, Sockeye salmon/kokanee (Oncorhynchus nerka).

${ }^{\text {a Comp }}=$ number of comparisons. Of the comparisons in each study, ' $>$ ' represents the number where statistically the local population performed better than the foreign population, ${ }^{\prime}=$ ' represents the number where there was no difference between local and foreign population fitness and ' $<$ ' represents the number where the foreign population performed better than the local population.

${ }^{b}$ Replicated twice for two interpopulation comparisons.

isons (Tables 1, 2 and Supplementary Table S1). Note that, we only considered studies that (i) measured fitness components (for example, survival and reproductive success) or (ii) measured reasonable proxies of fitness components (for example, putative survival from recovery rates); to date, studies in the wild fulfilling LA criteria have only provided data for (ii), with one exception (Donaghy and Verspoor, 1997). Studies also had to account for any differences in age-at-maturity between populations when comparing survival on the basis of adult recapture rates, to make such comparisons valid ones. Too few studies on different species precluded separate species assessments.

We first calculated the effect size of the relative proportion of recaptured 'local' and 'foreign' fish in each study using the log odds ratio (Lipsey and Wilson, 2001). We standardized our data using the following equation:

$$
\begin{aligned}
\mathrm{ES}_{\mathrm{LOR}}= & \log _{\mathrm{e}}\left[\frac{p_{\text {recapture population } A}}{1-p_{\text {recapture population } A}}\right]-\log _{\mathrm{e}} \\
& \times\left[\frac{p_{\text {recapture population } B}}{1-p_{\text {recapture population } B}}\right]
\end{aligned}
$$

where $E S_{L O R}$ was the effect size of the log odds

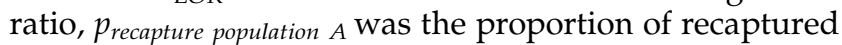
local fish and $p_{\text {recapture }}$ population $B$ was the proportion of recaptured foreign fish. A positive effect size would indicate that local fish survived better than foreign fish, whereas a negative effect size would indicate the opposite trend. We used the same method for studies involving the 'home vs away' criterion, but did not compare the two LA criteria because many interpopulation comparisons did not overlap between them (Tables 1, 2 and Supplementary Table S1). In the few comparisons with zero recaptures, we added 0.5 to these cells for analysis following Lipsey and Wilson (2001). For each effect size, we calculated an error term $\left(S E_{L O R}\right)$ using the following equation:

$$
\begin{aligned}
& \mathrm{SE}_{\mathrm{LOR}}= \\
& \sqrt{\frac{1}{n_{\text {recaptures pop A }}}+\frac{1}{1-n_{\text {recaptures pop A }}}+\frac{1}{n_{\text {recaptures pop } \mathrm{B}}}+\frac{1}{1-n_{\text {recaptures pop } \mathrm{B}}}}
\end{aligned}
$$


Table 2 Summary of salmonid fitness data related to the 'home vs away' criterion of local adaptation

\begin{tabular}{|c|c|c|c|c|c|c|c|}
\hline \multirow[t]{2}{*}{ Species } & \multirow[t]{2}{*}{ Fitness measure } & \multirow[t]{2}{*}{ Life stage } & \multirow[t]{2}{*}{ Comp ${ }^{\mathrm{a}}$} & \multicolumn{3}{|c|}{ Fitness, Home vs Away } & \multirow[t]{2}{*}{ Reference } \\
\hline & & & & $>$ & $=$ & $<$ & \\
\hline \multicolumn{8}{|c|}{ Studies in the wild } \\
\hline AS & Survival (adult recovery rate) & Smolt to adult return & $15^{\mathrm{b}}$ & 9 & 6 & - & Ritter, 1975 \\
\hline AS & Survival (adult recovery rate) & Smolt to adult return & $5^{c}$ & 5 & - & - & Jonasson, 1996 \\
\hline AS & Survival & Fertilized egg to hatch & 2 & 1 & 1 & - & Donaghy and Verspoor, 1997 \\
\hline AS & Survival (recapture rates) & Fry to age $0+$ in freshwater & 6 & - & 6 & - & Houde et al., 2010 \\
\hline CS & Survival (adult recovery rate) & Fry $(5-8 \mathrm{~g})$ to adult return & 2 & - & - & 2 & Hancock and Marshall, 1985 \\
\hline CS & Survival (adult recovery rate) & Fry (5-6g) to adult return & 3 & 2 & 1 & - & Federenko and Shepherd, 1986 \\
\hline $\mathrm{CO}$ & Survival (adult recovery rate) & Early juvenile to adult return & 2 & 1 & 一 & 1 & Bagatell et al., 1980 \\
\hline $\mathrm{CO}$ & Survival (adult recovery rate) & Early juvenile to adult return & 1 & 1 & - & - & Bagatell et al., 1981b \\
\hline $\mathrm{CO}$ & Survival (adult recovery rate) & Early juvenile to adult return & 3 & 3 & - & - & Fuss and Rasch, 1981 \\
\hline MS & Survival (adult recovery rate) & Smolt to adult return & $4^{\mathrm{d}}$ & 4 & - & - & Mayama et al., 1989 \\
\hline BT & Survival (tag return rate) & Smolt to adult & 2 & 1 & 一 & 1 & Bartel et al., 2001 \\
\hline \multicolumn{8}{|c|}{ Laboratory studies } \\
\hline AS & Survival (pH) & Alevin to 69 days post-hatch & 2 & 1 & 1 & & Fraser et al., 2008 \\
\hline CS & Survival (water chemistry) & Eyed egg to yolk absorption & 2 & - & 2 & - & Evans et al., 2010 \\
\hline SS & Survival (temperature) & Fertilized egg to emergence & 6 & 4 & 2 & - & Beacham and Murray, 1989 \\
\hline SS & Survival (temperature) & Fertilized eggs to emergence & 2 & - & 2 & - & Hendry et al., 1998 \\
\hline $\mathrm{CH}$ & Survival (temperature) & Fertilized eggs to emergence & 4 & 3 & - & 1 & Beacham and Murray, 1986 \\
\hline EG & Survival (temperature) & Hatch to emergence & 6 & 4 & 2 & - & Haugen and Vollestad, 2000 \\
\hline
\end{tabular}

Abbreviations: AC, Arctic charr (Salvelinus alpinus); AS, Atlantic salmon (Salmo salar); BC, Brook charr (Salvelinus fontinalis); BT, Brown trout (Salmo trutta); CH, Chum salmon (Oncorhynchus keta); CO, Coho salmon (Oncorhynchus kisutch); CS, Chinook salmon (Oncorhynchus tshawtyscha); EG, European grayling (Thymallus thymallus); LC, Lake charr (Salvelinus namaycush); LW, Lake whitefish (Coregonus clupeaformis); MS, Masou salmon (Oncorhynchus masou); PS, Pacific salmon, general (Oncorhynchus spp.); RT, Rainbow trout (Oncorhynchus mykiss); SS, Sockeye salmon/kokanee (Oncorhynchus nerka).

${ }^{a}$ Comp $=$ number of comparisons. Of the comparisons in each study, ' $>$ ' represents the number where statistically the home population performed better in the home environment than when away, ' =' represents the number where there was no difference between home and away fitness, and ' $<$ ' represents the number where the home population performed better when away. Species codes are found in Table 1 .

${ }^{b}$ Replicated twice for four interpopulation comparisons.

${ }^{c}$ Replicated three times for one interpopulation comparison and twice for another interpopulation comparison.

${ }^{\mathrm{d}}$ Replicated twice for two interpopulation comparisons.

The weights $\left(w_{L O R}\right)$ associated with each effect size estimate were then calculated using:

$$
\mathrm{w}_{\mathrm{LOR}}=\frac{1}{\mathrm{SE}_{\mathrm{LOR}}^{2}}
$$

We used $E S_{L O R}$ as the dependent variable in our metaanalysis, and $w_{L O R}$ was included to weight each effect size to account for differences in sample size across studies. We were interested not only in the overall effect size but also in the degree to which effect size may be influenced by geographic distance, or whether the study was peer-reviewed on the basis of the metric of originating from the primary vs secondary literature. We thus included these variables as fixed effects in our linear mixed-effects models, and study as a random effect to account for any within-study bias. Implicit in models incorporating geographic distance was that this was a reasonable proxy of the extent to which populations were exposed to differing local selective pressures.

Our approach to the analysis was twofold. First, we assessed whether there was a significant overall effect size for comparisons involving 'local vs foreign' and 'home vs away' criteria. This was done by testing for a significant intercept in our mixed-effects models. Second, we investigated whether our fixed effects had any influence on the magnitude of the effect size estimates. We began with a full model including an interaction between geographic distance and peer review, and reduced models in a stepwise manner. We used maximum likelihood to allow for comparison between models incorporating different fixed effects, and compared model fit using both Akaike's Information Criterion and log likelihood ratio tests. Geographic distance was $\ln$ transformed because of the broad range of distances among studies. All analyses were carried out using the lme function in S-Plus 6.1 (Insightful Corp., Seattle, WA, USA).

The possibility of publication bias of positive results was assessed by (i) producing and visualizing funnel plots of the standard error of the log odds ratio $\left(\mathrm{SE}_{\mathrm{LOR}}\right)$ vs the log odds ratio effect size $\left(E S_{L O R}\right)$ (Light and Pillemer, 1984; Supplementary Material) and by (ii) formally assessing whether peer review had any influence on effect size in a combined dataset of both LA criteria in our mixed effects models.

To quantify the extent of LA across studies in the wild, we determined the overall proportion of statistically significant interpopulation comparisons wherein 'local vs foreign' or 'home vs away' criteria were accepted vs when they were rejected. When statistical significance was not assessed for comparisons in the original study, we used Fisher's exact tests to assess statistical significance on the raw data. Owing to the overall limited number of data points for our analyses, and the limited statistical power for detecting fitness differences in some studies (for example, Ritter, 1975), we also calculated the proportion of comparisons where the 'local' or 'home' population fitness relative to the 'foreign' or 'away' population exceeded one. We repeated these same assessments with an inclusion of laboratory studies, 
which added 11 new studies (Tables 1, 2 and Supplementary Table S1). To be included in these analyses, laboratory studies had to provide clear information on known environmental differences between salmonid populations that were testable under common environmental conditions. Such studies clearly do not adequately typify the natural environment, so they were excluded in our formal meta-analysis. There are, however, many conservation situations in salmonids where studies in the wild are not permissible and decision making may depend on results from lab studies (for example, Fraser et al., 2010). Lab studies may also confirm the relative importance of particular traits implicated in putative LA. We did not, however, compare the extent of salmonid LA in wild relative to lab studies, because the two categories of study, thus far, have been largely conducted at different life stages (Table 1 and 2 and Supplementary Table S1).

\section{Fitness data-Results and Discussion}

Meta-analysis: We found a significant, positive overall effect size for both local-foreign $\left(t_{33}=2\right.$. $60, P=0.014$; Figure 1a) and home-away criteria $\left(t_{34}=2.21, P=0.034\right.$; Figure 1b). This suggested that local populations outperform foreign populations in their home environment, and that survival is higher in home environments relative to being transplanted to different environments. In addition, we found an effect of geographic distance for both LA criteria (Figure 1), although this effect was more pronounced for home-away comparisons, and it depended on the type of model comparison that is used (Supplementary Table S2). We did not find a significant influence of peer review for local-foreign comparisons. While there was some indication that including peer review in the model improved model fit for home-away comparisons, this effect disappeared when geographic distance was included (Supplementary Figure S1; Supplementary Table S2). Funnel plots revealed no asymmetric distributions caused by publication bias. That is, there was no evidence that bottom left-hand sides of the plots were biased towards non peer-reviewed works or contained no data; on the contrary, peer-reviewed studies reported negative results (Supplementary Figure S1).

\section{Extent of LA}

Over all statistically significant interpopulation comparisons involving studies in the wild, $77.3 \%$ (51 of 66 comparisons) were in favour of the local or home salmonid population (Table 3). Across all 93 significant and nonsignificant comparisons in the wild, the local/ home population had, on average, 1.20 times higher fitness (median $=1.44$ ) over foreign populations or relative to being away, although with considerable variability (range: 6.46 times less to 37.9 times more the average fitness) (Supplementary Table S1). With the inclusion of lab studies, $82.3 \%$ of statistically significant comparisons (79 of 96) were in favour of the local/home population, and the average local/home fitness advantage across all 143 comparisons was 1.23 times (median $=1.36$ times). In the 47 comparisons with no statistical significance, there was no trend for fitness to be greater (that is, exceed a ratio of 1:1) in the local or home population (wild and lab studies, respectively, local-foreign: 6/13 and 4/11 comparisons towards the local population; home-away:
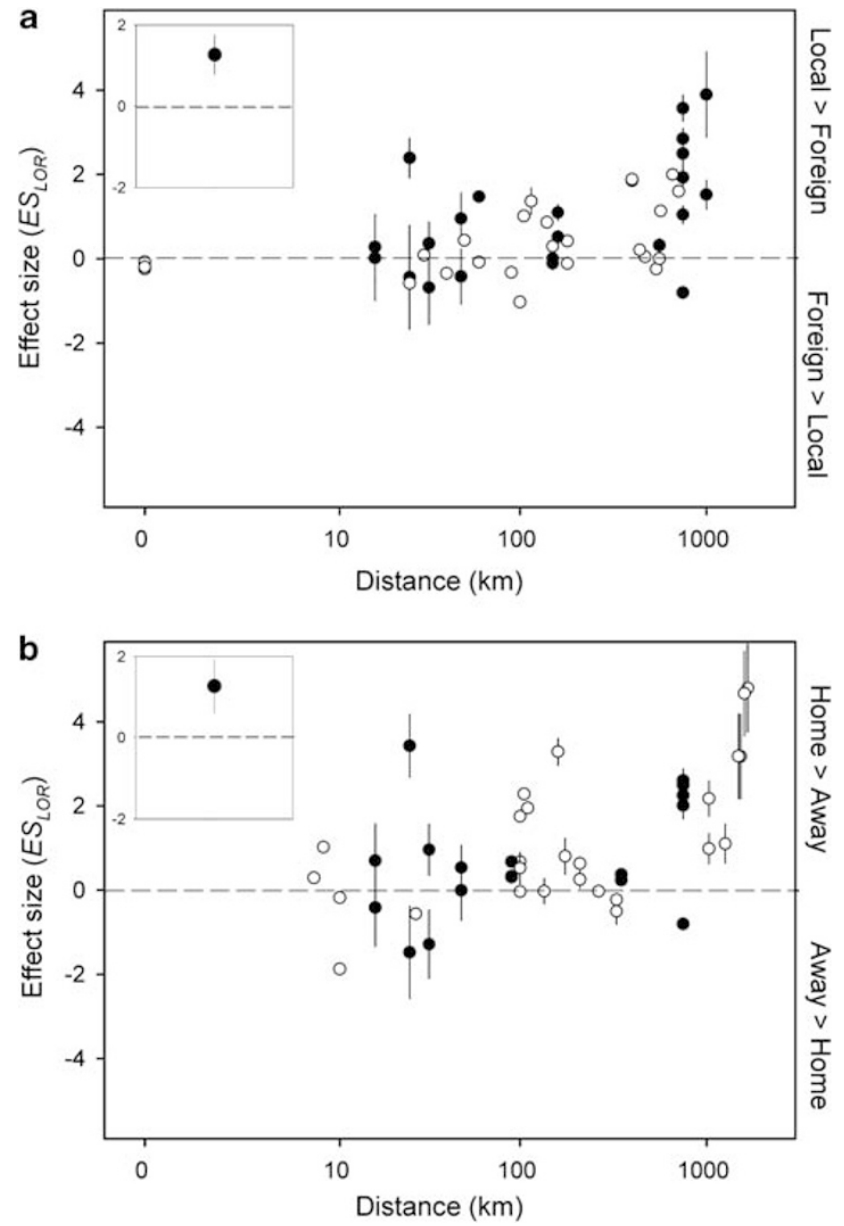

Figure $1 \mathrm{Log}$ odds ratio effect size $\left(E S_{L O R}\right)$ plotted against geographic distance $(\mathrm{km})$ for (a) local vs foreign comparisons and (b) home vs away comparisons involving salmonids. The dashed line represents zero effects and open circles denote studies that were not from the primary literature; closed circles represent primary literature studies. Inset graphs are overall effect sizes and error bars represent $S E_{L O R}$. Data are from the studies listed in Tables 1 and 2; complete details of the data are found in Supplementary Table S1.

Table 3 Summary statistics for local-foreign and home-away criteria of local adaptation in salmonids

\begin{tabular}{lcccc}
\hline Criterion & Local & $\begin{array}{c}\text { No } \\
\text { diff. }\end{array}$ & $\begin{array}{c}\text { Foreign/ } \\
\text { Away }\end{array}$ & $\begin{array}{c}\text { Total number } \\
\text { of comparisons }\end{array}$ \\
\hline $\begin{array}{l}\text { Local vs Foreign } \\
\quad \text { Studies in the wild }\end{array}$ & 24 & 13 & 11 & 48 \\
$\quad$ Laboratory studies & 16 & 11 & 1 & 28 \\
Combined & 40 & 24 & 12 & 76 \\
& & & & \\
Home vs away & 27 & 14 & 4 & 45 \\
$\quad$ Studies in the wild & 12 & 9 & 1 & 22 \\
Laboratory studies & 39 & 23 & 5 & 67 \\
Combined & & & & \\
Both criteria & & & & \\
$\quad$ Studies in the wild & 51 & 27 & 15 & 93 \\
$\quad$ Laboratory studies & 28 & 20 & 2 & 50 \\
$\quad$ Combined & 79 & 47 & 17 & 143 \\
\hline
\end{tabular}

The table reports the total number of interpopulation comparisons wherein either (i) the local/home or foreign/away population had a statistically significant fitness advantage or (ii) there was no statistical difference ('No difference'). 
5/14 and 6/9 comparisons towards the home population) (Supplementary Table S1).

Collectively, and depending on the conservativeness of the assessment, the extent of salmonid LA ranged from 54.8 to $69.9 \%$. First, assuming that all nonsignificant comparisons did not reflect LA, the local/home population had greater fitness than the foreign population or when 'away' in 55.2\% of comparisons (79 of 143) or in $54.8 \%$ of comparisons (51 of 93) for studies in the wild only (Table 3). Second, assuming that any comparison reflected LA if the local-foreign or home-away fitness ratio exceeded one (Figure 1 and Supplementary Table S1), the extent of LA was 69.9 (100 of 143 comparisons) or $66.7 \%$ (62 of 93 comparisons) for studies in the wild only.

In summary, based on quantitative measures that could be compared with other studies, the estimates on the extent of LA reported here support that salmonids do not differ in their frequency of LA relative to plants ('local vs foreign' comparisons only: 67.1 (51 of 76 comparisons) vs $71 \%$ (740 or 1042 comparisons) from Leimu and Fischer, 2008, Fisher's Exact test, $P=0.78$ ) or other assessed taxa, mainly plants and invertebrates (67.1 (51 of 76 comparisons) vs 65\% (505 of 777 comparisons) from Hereford, 2009, $P=0.92$ ).

The frequency with which foreign populations outperformed local populations (22.9-35.4\%; Table 3) also suggests that this is not a rare occurrence in salmonids. A lack of fulfillment of LA criteria does not definitively preclude the existence of LA; for instance, temporal variation in selection or gene flow could result in local and foreign populations exhibiting similar fitness at the time of comparison. Yet this result is intriguing because salmonids are expected to adapt quickly to their local environments (see section on the speed of LA below). It implies that other factors, specifically genetic drift, gene flow and phenotypic plasticity, often affect salmonid LA (Travisano et al., 1995; Hereford, 2009). Why these factors may or may not hinder LA in particular population systems represents an understudied element of salmonid research.

\section{Geographic scale of LA}

LA was evident in salmonids at a variety of spatial scales (Figure 1), from several kilometres in European grayling, Thymallus thymallus (Haugen and Vollestad, 2000) to $>1000 \mathrm{~km}$ in Atlantic salmon, Salmo salar (Ritter, 1975). In addition, as suggested by previous authors (Ritter, 1975; Reisenbichler, 1988), LA generally became stronger as the geographic scale increased at which 'local vs foreign' or 'home vs away' comparisons were made (Figure 1).

A salient feature of this review, however, is that there may be greater variability in the magnitude of LA in salmonids at geographic scales of $\leqslant 100-200 \mathrm{~km}$ (Figure 1). At $\leqslant 100 \mathrm{~km}$, for example, a considerable proportion of foreign-local fitness ratios exceeded one (47.1\% (16 of 34$) ; 60.0 \%$ (12 of 20 ), excluding lab studies) or local populations performed equally well or better when 'away' than when 'home' (32.4\% (11 of 34); $40.0 \%$ (8 of 20), excluding lab studies). In other words, at successive $200 \mathrm{~km}$ intervals from $0-200 \mathrm{~km}$ to $400-$ $600 \mathrm{~km}$, the percentage of comparisons consistent with fulfilling LA in each interval increased $(62.8,76.0$ and $80.0 \%$ ); beyond $600 \mathrm{~km}$, it increased to $92.3 \%$ (Figure 1 and Supplementary Table S1). Therefore, although geographically distant salmonid populations are almost unanimously exposed to very different selective regimes, those between more geographically proximate populations can be similar or different.

\section{Other aspects of the 'scale' of LA}

An additional aspect of the 'scale' of LA that we considered was fitness trade-offs. If being adapted to one environment results in maladaptation in another environment, population pairs raised in each others environments should always perform better in their home environment (Kawecki and Ebert, 2004; Hereford, 2009). Only four salmonid studies in the wild have assessed both local-foreign and home-away criteria (Supplementary Table S1); statistically-speaking, the local population always performed better in its home environment in only two of seven comparisons. Nonetheless, a relationship between geographic distance and fitness for each LA criterion (Figure 1) suggests that trade-offs associated with LA do exist in salmonids, and that they are more likely at larger spatial scales where greater differences in environmental features are expected. Alternatively, because isolation by distance typically characterizes genetic differentiation among anadromous populations, gene flow between distant populations is more restricted and therefore less likely to counteract the effect of selection driving LA.

Two aspects of the 'scale' of LA, which we did not consider were (i) whether LA was more or less prominent in salmonids depending on the life stage and (ii) 'adaptation-by-time' (temporal adaptation within the same environment). For (i), generalities await further study because most studies of wild fish have been done on later life stages and most laboratory studies have been restricted to early life stages only. We also urge that potential adaptation to the marine phase of anadromous salmonid lifecycles (Box 2) continues to be an overlooked issue for salmonid conservation (Taylor, 1991). For (ii), Hendry and Day (2005) discussed the theory behind the evolution of 'adaptation-by-time', and there are several examples of spring/summer/winter breeding runs within rivers in some salmonids, which may represent this phenomenon (for example, Waples et al., 2004). In fact, a few data points from our quantitative survey may reflect such temporal adaptation rather than spatial adaptation (Bagatell et al., 1980; Hendry et al., 1998; Beacham and Murray, 1986). Further distinguishing between temporal and spatial adaptation might help to reveal additional insights into the 'scale' of salmonid LA.

\section{Fitness data caveats}

No comparisons in our meta-analysis came from nonanadromous populations, so our conclusions are most relevant to anadromous populations. Moreover, all 12 data points from lab studies of nonanadromous populations were derived from one study (Haugen and Vollestad, 2000). Potentially greater spatial and temporal isolation in the habitats that nonanadromous populations inhabit could more readily favour LA than in anadromous populations. Indeed, at neutral genetic markers, nonanadromous populations generally exhibit greater levels of genetic differentiation $\left(F_{\mathrm{ST}}\right)$ than anadromous populations (DeWoody and Avise, 2000). Conversely, the life histories of nonanadromous popula- 
Box 2 Potential for local adaptation to the marine phase in anadromous salmonids

\begin{abstract}
The seemingly homogeneous marine environment suggests that LA likely occurs at larger spatial scales than in freshwater. Survival in freshwater (egg-to-smolt) is often lower than in seawater (smolt-to-adult), so selective pressures also have a potentially greater influence on 'freshwater' than 'marine' adaptation. Thus, some authors suggest that most salmonid LA relates to selective pressures in freshwater (Quinn, 2005; Garcia de Leaniz et al., 2007). Yet marine areas differ in productivity, salinity, temperature, current regimes, prey items, seasonality and predators, as do marine estuaries. Furthermore, both highly varying migration distances (to and from feeding grounds) and persistent spatiotemporal differences in marine distributions have been found between populations of several salmonids (e.g. Svardson and Fagerstroem, 1982; Healey, 1983; Jessop, 1986; Weitkamp et al., 1995). The latter have been shown to be geneticallydetermined in some cases, where F1 hybrids exhibited intermediate distributions relative to parental populations (Brannon and Hershberger, 1984; Kallio-Nyberg et al., 2000).

Perhaps most importantly, adaptations to marine and freshwater environments are probably inseparably linked. Collective phenotypic differentiation between migratory populations is often difficult to understand without considering it in the context of the entire lifecycle (e.g. Fraser and Bernatchez, 2005). Further inclusion of the marine environment in salmonid LA research is timely because oceanic changes are implicated in the declines or extirpation of some salmonid population groups (e.g. COSEWIC 2006). Such research may also help to reveal why escaped farmed salmonids can outcompete wild salmonids in freshwater stages but then fare poorly in the ocean (see McGinnity et al., 2003), or why nonanadromous salmonids have had greater overall success when introduced to nonnative environments than anadromous ones (e.g. Utter, 2004; Quinn, 2005).
\end{abstract}

tions (for example, no migrations between freshwater and marine habitats) and other aspects such as lower population sizes might slow down or impede LA.

It also cannot be ruled out that apparent survival differences in some cases may reflect other entities such as different migrations at sea when sampling was conducted/completed (for example, Bartel et al., 2001). Furthermore, many studies, particularly those predating the 1990s, either did not explicitly account for maternal effects or rearing/transfer/release effects, or details were not available to assess whether such effects were negligible in influencing study results (but see Bagatell et al., 1981a,bc). Where applicable, our analysis also assumed that the potential fitness effects of hatchery rearing were equal across the populations being compared (see Fraser, 2008)

Finally, most studies assessed only one or a few components of fitness, usually just survival or a proxy of survival, and they rarely evaluated lifetime success. This was unsurprising because of the logistical constraints of conducting long-term studies on salmonids, but it prevented some potentially very useful analyses. For example, we are unaware of any research on salmonids that has examined whether the extent of being locally adapted confers higher mating success, despite theoretical predictions (Correia et al., 2010). One must therefore be cognizant that salmonid LA (for example, ability to swim upstream to a distant spawning ground) might not necessarily translate into perceptible differences in mating success. More importantly, the apparent lack of LA in some studies could be a result of incomplete fitness surrogates (see Hereford, 2009). Conflicting selection pressures on survival vs reproduction, or at different life stages, might have made it difficult to detect LA.

Overall, as more LA studies are conducted on salmonids, similar or extended quantitative surveys could be carried out to account for potential effects on the extent and scale of LA of separate species, life history types (anadromous, resident, lake migratory and so on), varying population sizes, particular life stages, different environmental gradients and/or varying geographic scales.

\section{Extent and scale of LA inferred from phenotypic/ molecular approaches}

We found six chief phenotypic/molecular approaches that have been used to detect natural selection in salmonids, and to relate this to either putative selective agents, specific traits implicated in putative LA, and/or the likely extent and scale of LA (Table 4). We did not review each approach quantitatively because too few studies have been conducted on salmonids for some approaches. Others are discussed elsewhere (Approach IV, see 'Speed of LA' below), whereas others have only been used sparingly at the within-population level (Approaches V, VI). We thus focused more on what Approaches I-III revealed about salmonid LA. Collectively, they provided compelling evidence that LA may be prevalent and may occur at a variety of spatiotemporal scales (and traits), notwithstanding the caveat that detecting true LA with these approaches is either very difficult or impossible (Endler, 1986; Garcia de Leaniz et al., 2007; Table 4).

\section{Agents of and traits under selection}

Abiotic or biotic environmental factors that may act as selective agents in salmonids include temperature, photoperiod, surface geology, water chemistry, river hydrology, migration distance, pathogens, parasites, prey, predators and interspecific competitors. Trait or gene variation that is potentially coupled with these selective agents (whether genetically based or inferred to be genetically based) is extensive and will not be exhaustively reviewed here. It extends to all aspects of phenotype, including behaviour, life history, phenology, morphology and physiology (reviewed extensively in Taylor, 1991; Garcia de Leaniz et al., 2007; see also examples included in Table 4).

A key question then is: which traits might be more likely to exhibit LA in salmonids? This is obviously difficult to discern, for the functions of individual traits and their potential link to fitness are most often inseparably linked with other traits (Gould and Lewontin, 1979). Furthermore, very few salmonid studies have experimentally manipulated single traits to measure consequences for fitness (Table 4, also a common trend in studies of LA across taxa: Kawecki and Ebert 2004). If the common-garden laboratory experiments conducted on putative selective agents in salmonids are any indication, an example of particularly strong LA may be pathogen resistance (Supplementary Table S1). For instance, populations of several species of Pacific salmon (Oncorhynchus spp.) inhabiting the Columbia River 
Table 4 Summary of main approaches (using phenotypic, genetic and/or environmental data) that have been used for detecting natural selection in salmonids and relating this to putative selective agents, specific traits implicated in putative LA, or the likely extent or scale of LA

Approach, general hypothesis Salmonid examples, traits/genes involved Reference

I. Correlation with environmental factors

(a) 'Divergence with gene flow' / landscape genetics-negative association between the extent of phenotypic or habitat populations

(b) Clines selection invoked to explain clinal variation at phenotypic traits (best if corroborated by multiple traits)

(c) Countergradient variation selection invoked to explain expression of the same phenotype across an environmental gradient

(d) 'Phenotype-environment associations'-a demonstrable genetic basis of trait differentiation, differential gene expression or phenotypic plasticity, and a link with environmental/habitat factors

(e) Tests of parallel evolution-independent evolution of the same phenotypes or gene expression in unrelated for divergent selection in population differentiation

\section{Deviations from neutral expectations}

(a) $F_{\mathrm{ST}}$ vs $Q_{\mathrm{ST}}$ greater genetic differentiation at quantitative traits $\left(Q_{\mathrm{ST}}\right)$ than at neutral genetic markers $\left(F_{\mathrm{ST}}\right)$ suggests a role for divergent selection in population differentiation. Other cases: $Q_{S T}=F_{S T}$-selection cannot be disentangled from drift $Q_{S T}<F_{S T}$-stabilizing selection in population differentiation

(b) Single candidate gene approaches greater genetic differentiation at candidate genes potentially exposed to selection relative to selectively neutral genes suggests a role for divergent selection in population differentiation. Alternatively, clinal patterns that cannot be ascribed to neutral processes (for example. corroborated by analysis of neutral loci not showing clinal variation)

(c) Genome scans-role of selection invoked based on outlier loci, that is, loci at which genetic differentiation deviates from expectations of neutrality differentiation and the amount of gene flow between populations living in similar environments suggests a role

Trophic ecology and habitat use: AC, LW

Habitat or life-history and population structure: AS

Breeding/non-breeding habitat features, migration distance: BC

Nonbreeding habitat spatial segregation: AS

Breeding habitat features, reproductive traits: SS

Migration timing, spawning time: SS, CO

Growth and maturation of precocial males: MS

Production and use of carotenoids in migratory and nonmigratory forms: SS

Growth in relation to passage time and digestion rate: BT

Single phenotypic traits (many), for example: reviewed in PS, AS Integrative: behavioural, life history, morphological: LW, AS

Transcriptomics: differential gene expression among

populations or life-history types, related to physiological,

metabolic and immune function: LW, AS

Genomic basis of anadromous salinity tolerance

Parallel evolution of life history traits and gene expression between benthic and limnetic population pairs: LW

Parallel evolution of nonmigratory forms: SS

Parallel evolution of run-timing: CS

Embryonic traits: anadromous, resident, lake migratory BT

Embryonic traits and juvenile growth traits: $\mathrm{BC}, \mathrm{EG}, \mathrm{CO}$

Swimming behaviour, growth, morphology: LW

Early-late history traits: CS

Allele frequencies at MEP- $2 \times$ temperature, and latitude: AS MHC allelic diversity: AS, SS, BT, RT, CS

MHC allelic diversity $\times$ temperature, and latitude: AS

Clock gene loci: $\mathrm{CS}, \mathrm{CO}$

Salinity tolerance: BT

TAP polymorphisms: BT

Transferrin, somatolactin and p53 genes: CS

Tansaldolase gene expression: BT

Growth hormones 1\&2, transferrin, immunoglobin: CS

EST-linked microsatellites, comparing immune related versus nonimmune related genes: AS

EST-linked and anonymous microsatellites: BT

Amplified fragment length polymorphisms (AFLP): LW

Expressed sequence tag (EST) -linked microsatellites: AS

Transcriptomic scan of recently diverged subpopulations: AS

32,33

$34-44$

36

45,46

47

48

49

50

51

52

53

54

55

56

III. Integrative genomics approaches (for example QTL+transcriptomics/SNPS)

Combining different approaches and targeting several functional and biological levels to investigate the molecular basis of LA

Putative adaptive divergence between benthic and limnetic niches: LW

Putative adaptive divergence (genes associated with lipid synthesis and immunity function) between benthic and pelagic niches using RNA-seq and qPCR: LC

CS, SS, EG, AS

Early life history traits: AS; body morphology: BT

(b) Artificially-induced changes to populations or their habitats (eg. experimental manipulations of traits or selective agents)

(c) Temporary or seasonal environmental shifts

(natural/human induced)

Evolution following installation of a fish ladder: BT

V. Cohort analysis

Significant relationship between demography and trait values
Body size, age-specific survival and fitness: BC 
VI. Age or life stage analysis

Selection results in differences in trait or gene frequency

distributions between age classes or life stages

Abbreviations: AC, Arctic charr (Salvelinus alpinus); AS, Atlantic salmon (Salmo salar); BC, Brook charr (Salvelinus fontinalis); BT, Brown trout (Salmo trutta); CH, Chum salmon (Oncorhynchus keta); CO, Coho salmon (Oncorhynchus kisutch); CS, Chinook salmon (Oncorhynchus tshawtyscha); EG, European grayling (Thymallus thymallus); LC, Lake charr (Salvelinus namaycush); LW, Lake whitefish (Coregonus clupeaformis); MS, Masou salmon (Oncorhynchus masou); PS, Pacific salmon, general (Oncorhynchus spp.); RT, Rainbow trout (Oncorhynchus mykiss); SS, Sockeye salmon/kokanee (Oncorhynchus nerka).

Main sources from which the approaches have been derived or modified: Endler, 1986; Conover and Schultz, 1995; Schluter, 2000; Merila and Crnokrak, 2001; Bernatchez, 2004; Beaumont and Balding, 2004. Ref = reference. Species codes are found in Table 1.

References: 1, Gislason et al., 1999; 2, Lu and Bernatchez, 1999); 3, Vaha et al., 2007; 4, Dionne et al., 2008; 5, Fraser and Bernatchez, 2005; 6, Potvin and Bernatchez, 2001; 7, Wood and Foote, 1996; 8, examples in Quinn, 2005; 9, Spence and Hall, 2010; 10, Morita and Nagasawa, 2010; 11, Craig and Foote, 2001; 12, Nicieza et al., 1994; 13, Taylor, 1991; 14, Garcia de Leaniz et al., 2007; 15, Bernatchez, 2004; 16, Fraser et al., 2010; 17, Derome et al., 2006; 18, St-Cyr et al., 2008; 19, Normandeau et al., 2009; 20, Tymchuk et al., 2010; 21, Giger et al., 2006; 22, Giger et al., 2008; 23, Nolte et al., 2009; 24, Taylor et al., 1996; 25, Waples et al., 2004; 26, Jensen et al., 2008a; 27, Perry et al., 2005; 28, Koskinen et al., 2002; 29, McClelland and Naish, 2007; 30, Rogers et al., 2002; 31, Kinnison et al., 2008; 32, Jordan and Youngson, 1991; 33, Jordan et al., 2005; 34, Landry and Bernatchez, 2001; 35, Consuegra et al., 2005; 36, Dionne et al., 2007; 37, Consuegra and Garcia de Leaniz, 2008; 38, Dionne et al., 2009; 39, Miller et al., 2001; 40, Campos et al., 2006; 41, Hansen et al., 2007; 42, Aguilar and Garza, 2006; 43, Evans and Neff, 2009; 44, Turner et al., 2009; 45, O'Malley et al., 2007; 46, O'Malley et al., 2010; 47, Larsen et al., 2008; 48, Jensen et al., 2008b; 49, Ford, 2000; 50, Amstutz et al., 2006; 51, Heath et al., 2006; 52, Tonteri et al., 2010; 53, Hansen et al., 2010; 54, Campbell and Bernatchez 2004; 55, Vasemagi et al., 2005; 56, Roberge et al., 2007; 57, Rogers and Bernatchez, 2007; 58, Bernatchez et al., 2010; 59, Goetz et al., 2010; 60, Hendry et al., 2000; 61, Haugen and Vollestad, 2000; 62, Kinnison et al., 2008; 63, Einum and Fleming, 2000; 64, Pakkasmaa and Piironen, 2001; 65, Haugen et al., 2008; 66, Morrissey and Ferguson, 2009; 67, McGinnity et al., 2004.

drainage have evolved sympatrically with the parasite Ceratomyxa shasta and are far more resistant to bacterial infection than allopatric populations (for example, Buchanan et al., 1983; Hemmingsen et al., 1986). Another case of potentially strong salmonid LA involves the migratory behaviour of newly emerged fry. In many salmonids, innate differences in compass-orientation behaviour between outlet and inlet stream populations correspond to specializations in movement from incubation areas to habitats favourable to feeding and growth (for example, Raleigh, 1971; Kelso et al., 1981). Similarly, traits associated with photoperiodicity (for example, runtiming and spawning time) and hydrology or migration distance (for example, body morphology and swimming performance) may also be under particularly strong selective pressures across different salmonids (Taylor, 1991; Garcia de Leaniz et al., 2007). The application of particular phenotypic molecular approaches discussed below provides an indirect test of determining which traits are most likely under divergent selection (for example, $Q_{S T}-F_{S T}$, and thus which may be mediating LA.

\section{Approach I}

The most common approach applied to studying salmonid LA has been to correlate differentiation at the phenotypic or molecular level with environmental factors in various ways (Approach I and Table 4). For example, several studies have explicitly tested the 'divergence-with-gene flow' model and all found results consistent with its prediction (Table 4). A variety of phenotypic traits and environmental or habitat features throughout the lifecycle were considered. Most studies were conducted on trophically- or migration-differentiated sympatric populations inhabiting post-glacial lakes. Putative LA ranged from smaller geographic scales (that is, the same breeding habitats; Wood and Foote, 1996), to a few kilometres (Gislason et al., 1999; $\mathrm{Lu}$ et al., 1999), and to a 'regional' scale of $25-100 \mathrm{~km}$, encompassing multiple populations occupying different rivers (Potvin and Bernatchez, 2001; Fraser and Bernatchez, 2005). The scale of putative LA in two landscape genetic studies on anadromous Atlantic salmon populations was also variable. It ranged from distances of $\leqslant 20-\geqslant 100 \mathrm{~km}$ between mainstem, headwater and tributary populations within a large river system (Vaha et al., 2007), to distances up to several hundred kilometres between regional groups of ecologically- and genetically-related populations occupying separate rivers (Dionne et al., 2008). Several studies have also shown clinal (latitudinal) variation in phenological or life history traits (for example, run-timing and age-atmaturity) in relation to temperature or day length (Table 4). Usually, the role of selection in differentiation was invoked at the scale of 100s to 1000s of kilometers in these studies. Finally, parallel evolution across multiple lakes of the same genetically-based phenotypic differentiation (and in one case gene transcription) has been observed at scales of just a few kilometres between ecotypes occupying distinct, adjacent ecological niches (Table 4).

\section{Approach II}

A second major approach used assesses whether greater genetic differentiation occurs at traits/or genes potentially exposed to selection relative to selectively neutral genes, or alternatively whether specific candidate loci are correlated with environmental features not ascribed to neutral differentiation (Approach II). For instance, all six salmonid studies comparing genetic differentiation at neutral molecular markers $\left(F_{S T}\right)$ and quantitative traits $\left(Q_{S T}\right)$ found that average $Q_{S T}$ exceeded $F_{S T}$ over a total of eight interpopulation comparisons, though not at all (20-60\%) individual traits examined, and generally only early life traits were studied (Table 4). These differences were detected between populations separated by a few to $100 \mathrm{~km}$. The approach has also been used to infer the most likely traits implicated in LA. In juvenile 'dwarf' and 'normal' lake whitefish (Coregonus clupeaformis) that occupy 
limnetic and benthic habitats across multiple lakes, Rogers et al. (2002) found that $Q_{S T}$ significantly exceeded $F_{S T}$ for two of three swimming behaviour traits, one of four meristic traits (gill rakers), but zero of 10 morphological traits. Thus far, however, the ways in which $F_{S T}-Q_{S T}$ comparisons have been implemented in salmonids have a number of caveats meriting further attention (for example, see Hendry, 2002; Whitlock, 2008).

Single candidate gene studies have also provided insight into the potential scale of salmonid LA, especially Major Histocompatibility complex (MHC) studies owing to potentially strong indications of immunity-related selection at MHC alleles and the capability to link such variation to selective agents in nature (for example, pathogens and parasites; Garrigan and Hedrick, 2003). Pathogens and parasites in riverine environments are generally assumed to be widespread across large geographical scales but to have highly heterogeneous distributions at microgeographical scales (Bakke and Harris, 1998). The presence of specific pathogens and parasites can also change drastically even over short time spans causing both spatially and temporally fluctuating selection (Garrigan and Hedrick, 2003). Thus, diversifying selection at MHC loci is expected to occur at small geographical scales and shift over time.

Results from several salmonid studies of variation at MHC-related loci generally concur with this prediction. Evidence for selection at MHC loci has been found at microgeographical scales (within a few kilometres), and with no general tendency of LA to increase with geographical distance, at least at the scale of a few hundred kilometres (Landry and Bernatchez, 2001; Miller et al., 2001; Aguilar and Garza, 2006; Jensen et al., 2008a). Fewer studies have investigated patterns of temporal selection, with some finding either temporally stable or fluctuating selection (Miller et al., 2001; Coughlan et al., 2006; Hansen et al., 2007; Jensen et al., 2008b). Nevertheless, a study comparing MHC Class II diversity in Atlantic salmon with bacterial diversity and temperature regimes in rivers along a North-South axis also suggests macrogeographical patterns of LA (Dionne et al., 2007). Positive relationships were found between MHC allelic diversity and, temperature or bacterial diversity, presumably reflecting selective responses to richer pathogen faunas in warmer water. Hence, putative LA at MHC loci can be viewed as a hierarchical process with different dynamics acting on different geographical scales. Yet a similar study on chinook salmon (Oncorhynchus tshawytscha) found no evidence for any MHC alleles to confer bacterial resistance (Evans and Neff 2009). Further research is merited to discern complexities related to the role of pathogen communities in the evolution of salmonid host LA.

Circadian (for example, CLOCK) genes have also recently attracted interest because of their role in photoperiodicity and determination of seasonal timing (phenology) (Lowrey and Takahashi 2004). For these loci, LA might be expected to occur at macrogeographical scales and mostly along a North-South axis as the photoperiod corresponding to the optimal timing of major life-history events will differ considerably along this axis (for example, adult or juvenile migration timing). A clinal pattern of CLOCK gene variation in chinook salmon populations along $>4000 \mathrm{~km}$ of Pacific coastline supports these predictions (O’Malley and Banks, 2008).
Genome scans screen large numbers of loci (100-1000s) to estimate the number and proportion of loci linked to genes under selection ('outlier' loci deviating from neutrality). In salmonids, this method has been used to test the hypothesis that divergent selection is implicated in the diversification of populations at several spatial scales (Table 4). For instance, lake whitefish ecotypes inhabiting limnetic ('dwarf') and benthic ('normal') niches across multiple small lakes exhibited 14 outlier loci (of 440 amplified fragment lengh polymorphism (AFLP) loci screened). Among these loci, six exhibited parallel patterns of divergence across ecotype pairs and they were associated with mapped quantitative trait loci (QTL) (mainly linked to growth) (Campbell and Bernatchez, 2004; Rogers and Bernatchez, 2007). Among eight Atlantic salmon populations originating from different spatial scales and with different life histories (anadromous and nonanadromous), Vasemagi et al. (2005) found that more outlier loci were detected at larger geographic scales than smaller ones (25 vs 9, of 95 genomic and expressed sequence tag-derived mini- and microsatellites loci screened). Overall, however, the causal link between such outlier loci, phenotypic traits under selection and fitness remains hypothetical, and in some cases outlier tests can fail to detect loci under selection (Michel et al., 2010). Future such research on salmonids could also benefit from integrating geographical information systems and genome scans to assess putative associations with environmental variables (see Meier et al., 2011; Joost et al., 2007).

Collectively, studies applying Approach II reveal quite different spatial scales of selection and potential LA, corresponding to spatial variation of the associated selection regimes. Hence, similar to results based on fitness data, there appears to be no single spatial scale at which LA occurs; it depends on the specific traits/genes, their functional role and the specific selection regimes.

\section{Approach III}

This approach combines methods at several levels of organization (for example, variation at the DNA, gene expression and phenotypic levels) towards understanding the molecular basis of trait adaptation (Table 4). An illustrative salmonid example comes from pairs of dwarf and normal lake whitefish inhabiting multiple small lakes. First, a joint comparison of phenotypic and genome wide transcriptomic differentiation identified the phenotypic (including physiological) traits most likely to be adaptive and hence those meriting further investigation for understanding the molecular basis of adaptation (reviewed in Bernatchez et al., 2010). Then the integrative use of linkage, phenotypic (pQTL) and gene expression (eQTL) mapping revealed the genetic architecture of these same phenotypic traits (Rogers and Bernatchez, 2007; Whiteley et al., 2008). Finally, combined pQTL and eQTL mapping revealed numerous candidate markers resisting the homogenizing effects of gene flow, hence, those genomic regions for which the influence of natural selection in the wild could be methodically tested (Bernatchez et al., 2010). Outlier genomic regions were mainly associated with growth or swimming behaviour, or gene expression associated with these functions (for example, protein synthesis and energy metabolism). 
Table 5 Studies focusing on the speed of adaptation in salmonid fishes, and the major phenotypic/gene expression changes associated with putative adaptation

\begin{tabular}{|c|c|c|c|}
\hline Example & G & Phenotypic or gene expression changes & Reference \\
\hline \multicolumn{4}{|c|}{ Natural colonization } \\
\hline SS & 100 & Adult body morphology, egg mass & Pavey et al., 2010 \\
\hline \multicolumn{4}{|c|}{ Introductions } \\
\hline SS & 14 & Breeding environment features: temperature, flow, migratory vigour & Hendry et al., 2000; Hendry, 2001 \\
\hline EG & $10-22$ & Breeding environment temperatures; embryo developmental rates & $\begin{array}{l}\text { Haugen and Vollestad, 2000; } \\
\text { Kavanagh et al., 2010; } \\
\text { Koskinen } \text { et al., } 2002\end{array}$ \\
\hline CS & 30 & Breeding environment features: temperature, flow, migratory vigour & Kinnison, et al., 2001, 2008) \\
\hline AS & 6 & $\begin{array}{l}\text { Precocial male maturity size threshold, oxidant defense, thyroid } \\
\text { hormone metabolism, defense against viral infections, } \\
\text { ribosomal RNA processing, transcription regulation, } \\
\text { and bacteriolytic function }\end{array}$ & $\begin{array}{l}\text { Aubin-Horth et al., 2006; } \\
\text { Roberge et al., } 2007\end{array}$ \\
\hline \multicolumn{4}{|c|}{ Adaptation to captivity } \\
\hline RT & $1^{\mathrm{a}}$ & Not determined & Araki et al., 2007 \\
\hline RT & $1^{\mathrm{a}}$ & Not determined & Caroffino et al., 2008 \\
\hline RT & $2^{\mathrm{a}}$ & Not determined & Araki et al., 2009 \\
\hline \multicolumn{4}{|c|}{ Fisheries-induced evolution } \\
\hline AS, PS & $6-10$ & Smaller size-at-maturity & $\begin{array}{l}\text { Ricker, 1981; } \\
\text { Quinn et al., } 2006\end{array}$ \\
\hline SS & 7-9 & Earlier run-timing & Quinn et al., 2007 \\
\hline EG & $10-22$ & Earlier age-at-maturity & Haugen, 2000 \\
\hline \multicolumn{4}{|c|}{ Evolution following fish ladder } \\
\hline BT & $6-7$ & Size-at-smolting, size-at-maturity & Haugen et al., 2008 \\
\hline \multicolumn{4}{|c|}{ Evolution to hydropower dams } \\
\hline CS & $15-20$ & Age-at-smolting (subyearling to yearling) & Williams et al., 2008 \\
\hline
\end{tabular}

Abbreviations: AC, Arctic charr (Salvelinus alpinus); AS, Atlantic salmon (Salmo salar); BC, Brook charr (Salvelinus fontinalis); BT, Brown trout (Salmo trutta); CH, Chum salmon (Oncorhynchus keta); CO, Coho salmon (Oncorhynchus kisutch); CS, Chinook salmon (Oncorhynchus tshawtyscha); EG, European grayling (Thymallus thymallus); LC, Lake charr (Salvelinus namaycush); LW, Lake whitefish (Coregonus clupeaformis); MS, Masou salmon (Oncorhynchus masou); PS, Pacific salmon, general (Oncorhynchus spp.); RT, Rainbow trout (Oncorhynchus mykiss); SS, Sockeye salmon/kokanee (Oncorhynchus nerka).

$\mathrm{G}=$ numbers of generations; $\operatorname{Ref}=$ reference; species codes are found in Table 1 .

\section{The speed of LA}

Studies following translocations, known environmental perturbations or trait manipulations offer the best available approaches for assessing how fast LA might evolve (Tables 4 and 5). Introduced salmonids can show evidence for phenotypic or gene expression differentiation associated with local environmental features and even restricted gene flow after 6-30 generations; in one case, the evolution of such differentiation from a common source population resulted in a 1.7-2.9 times greater fitness (survival) advantage to the local population after 30 generations (Unwin et al., 2003). Changes to selective regimes following the implementation of fish ladders or hydroelectric dams can result in phenotypic or life-history change within 6-15 generations. Adaptation to captivity, through either a relaxation of natural selective pressures or changes to them, can arise in salmonids even after one or two generations, resulting in fitness reductions of up to $40 \%$ per generation in one species (Table 5). Fisheries-induced evolution in the form of life-history change within several generations is also highly suspected in salmonids (Table 5). Heritabilities estimated from some of these works (typically $h^{2}=0.2-$ 0.4; see Carlson and Seamons, 2008) and likely selection differentials (for example, Williams et al., 2008) imply that there was ample opportunity for selection to operate quickly. What is largely unknown from these studies is the degree to which study populations had approached local phenotypic optima. Selection should be strongest and the speed of adaptation fastest just following human manipulations or disturbances, followed by a more gradual levelling off and a shift to stabilizing selection as new adaptive peaks are approached (Stockwell et al., 2003; Haugen et al., 2008). At least in the case of introduced sockeye salmon (O. nerka), the local phenotypic optimum for body depth differences between beach and river males may have been reached within 14 generations as the relative difference between the two forms was similar to that normally observed between native populations (Hendry, 2001).

\section{The molecular basis of LA}

Our knowledge of the molecular basis of salmonid LA is still rudimentary in part because most phenotypic traits in salmonids are affected by many segregating loci as well as a large amount of nongenetic variability. Furthermore, the whole genome duplication event in salmonids that occurred some 60 million years ago (Allendorf and Thorgaard, 1984) makes it difficult to decipher ortholog from paralog genes, which poses an additional constraint for the development identifying particular loci that may be implicated in LA (for 
example, 'true' single-nucleotide polymorphisms; Hayes et al., 2007). Another challenge is that a solid theoretical and analytical framework is currently lacking to identify the role of natural selection in driving LA at the gene expression level. Consequently, we are unaware of any salmonid study that, as yet, has established a causal link between molecular variation and fitness variation in terms of reproductive success and/or survival. But even if the exact genes implicated in salmonid LA remain unknown, questions regarding the molecular basis of LA can be resolved with more recent approaches (see Approach III above).

First, what is the genetic architecture of traits that are under selection: are few loci of large effect implicated in LA, or does LA involve many loci of small effect? Between dwarf and normal whitefish over four independent lakes, only a small proportion of screened loci (AFLP: $1.4-3.2 \%$ of 440; single-nucleotide polymorphisms: $1.5 \%$ of 6,094$)$ showed evidence of restricted gene flow relative to neutral expectations, suggesting they may be largely implicated in the divergence of the two forms (Campbell and Bernatchez, 2004; Renaut et al., 2010). Rogers and Bernatchez (2005) also reported that 8 of 27 QTL linked to growth may be implicated in dwarfnormal adaptive divergence, of which only two QTL showed parallel reductions of gene flow over the four lakes. This again suggested that only a small proportion of genes may be implicated in LA. Nevertheless, for a host of reasons, current approaches for detecting outlier loci may be biased towards finding genes of large effect (for example, Michel et al., 2010). More importantly, although salmonid studies have found that a few principle traits differ because of a few genes, it is very likely that many traits influence fitness differences between populations inhabiting different environments. Hence, in most cases, many genes of small or moderate effect undoubtedly underlie such fitness differences (see Michel et al., 2010; Schluter et al., 2010).

Second, do cases of parallel evolution of LA in salmonids involve the same genes or different ones? In dwarf and normal lake whitefish several hundred genes (approximately 11-15\% of the total number of expressed genes) were differentially expressed between pairs in each of four lakes, but nearly 100 genes showed a parallel pattern of expression both in the lab and in the wild (discussed in Bernatchez et al., 2010). Limnetic 'dwarfs' consistently showed significant overexpression of genes associated with survival through enhanced activity (energy metabolism, muscle contraction, homeostasis, lipid metabolism and detoxification). Genes associated with growth (protein synthesis, cell cycle and cell growth) were generally upregulated more so in the benthic 'normals'. Overall, LA in this case appears to involve a differential trade-off between growth, correlated fecundity and survival, which is mediated through the higher energetic cost of occupying the limnetic niche. Again, LA in lake whitefish also occurs at an exceptionally small spatial scale (different adjacent habitats within the same lakes).

A second case comes from the studies of Giger et al., 2006, 2008). They found that migratory and nonmigratory brown trout (Salmo trutta) sampled from independent, replicated vicinities consistently showed differential expression at several genes, but no differences were detected within life-history types. Intrigu- ingly, these genes may be consistently involved in preconditioning to seawater within anadromous populations, as similar patterns of expression were observed in both anadromous brown trout and anadromous Atlantic salmon (although the studies were based on wild-caught fish).

Eventually, it will be feasible to obtain genome scale insights into natural variation in salmonids through comparative sequencing of thousands of individual genomes from individual species (Tautz et al., 2010). Combined QTL mapping and genome scans should also help to establish a firmer link between the strength of selection acting on different genomic regions and its consequences for LA. Alternatively, across populations, one could genotype many 1000 s of single-nucleotide polymorphisms in a large number of phenotypicallydiverse individuals to perform whole-genome association mapping in nature, thereby circumventing the need to first conduct linkage mapping from families reared in controlled conditions (Slate et al., 2009). Overall, the speed of genomic data generation will soon outstrip the capacity of data analysis given current computational resources. Yet even once computational power is solved, the power offered by new generations of genomic tools for understanding LA will only be commensurate with: (i) the pertinence of questions being asked, (ii) the theoretical framework into which these questions are imbedded, (iii) the strength of the study design and (iv) integration with more 'classical' approaches of LA (for example, reciprocal transplants and translocations).

\section{Conclusion}

Although our review confirms that LA is prominent within salmonid species ( $\sim 55-70 \%$ of the time), we demonstrate that it may be less prevalent than has been traditionally assumed, and no different in frequency relative to other assessed taxa. Our review also reiterates that empirical data on salmonid LA remain sparse. Although salmonid LA occurs at a wide range of scales and, hence, is undoubtedly linked to these species' persistence (Waples, 1991), productivity (Schindler et al., 2010) and roles in community dynamics (Carlson et al., 2011), it is generally not as frequent or strong at smaller geographic scales. Salmonid LA also exists at both larger and smaller geographic scales than at the 'one river' level, the scale that has been traditionally accepted in the literature. A key research direction will continue to be the assessment of the extent and the scale of potential human-induced maladaptation (through climate and habitat alternations, fisheries, aquaculture, hatcheries, captive breeding and so on), as well as its consequences for salmonid evolution and persistence. Clarifying the magnitude of LA and fitness trade-offs in relation to geographic scale could also be very useful for optimising future species restoration efforts, including reintroductions and the maintenance of genetic variation within captive populations through artificial gene flow. Finally, only through an integrative approach that establishes a causal link between the molecular and phenotypic level will it be possible to understand the causes of diversity within salmonids. Owing to the resource demands of such endeavours, now more than ever it is imperative that greater collaboration between disciplines be undertaken. 


\section{Conflict of interest}

The authors declare no conflict of interest.

\section{Acknowledgements}

We thank C Primmer for the invitation to contribute to this special issue, as well as for his comments and those of J Grant, J Hutchings and two anonymous reviewers, on a previous version of the paper. We also thank D Bramwell from the Washington Department of Fisheries for kindly providing a number of secondary literature reports. This work was supported by Natural Sciences and Engineering Research Council of Canada (NSERC) Discovery Grants to DJF, LB and EBT, a NSERC Postdoctoral Fellowship to LKW, and by a Danish Natural Science Research Council grant to $\mathrm{MMH}$.

\section{References}

Adkison MD (1995). Population differentiation in Pacific salmon: local adaptation, genetic drift, or the environment? Can J Fish Aquat Sci 52: 2762-2777.

Aguilar A, Garza JC (2006). A comparison of variability and population structure for major histocompatibility complex and microsatellite loci in California coastal steelhead (Oncorhynchus mykiss Walbaum). Mol Ecol 15: 923-937.

Allendorf FW, Thorgaard GA (1984). Tetraploidy and the evolution of salmonid fishes. In: Turner BJ (ed). Evolutionary Genetics of Fishes. Plenum Press: New York, pp 1-53.

Allendorf FW, Waples RS (1996). Conservation and genetics of salmonid fishes. In: Avise JC, Hamrick JL (eds). Conservation Genetics: Case Histories from Nature. Chapman and Hall: New York, pp 238-280.

Amstutz U, Giger T, Champigneulle A, Day PJR, Largiader CR (2006). Distinct temporal patterns of transaldolase 1 gene expression in future migratory and sedentary brown trout (Salmo trutta). Aquaculture 260: 326-336.

Araki H, Berejikian BA, Ford MJ, Blouin MS (2008). Fitness of hatchery-reared salmonids in the wild. Evol Appl 1: 342-355.

Araki H, Cooper B, Blouin MS (2007). Genetic effects of captive breeding cause a rapid, cumulative fitness decline in the wild. Science 318: 100-103.

Araki H, Cooper B, Blouin MS (2009). Carry-over effect of captive breeding reduces reproductive fitness of wild-born descendants in the wild. Biology Letters 5: 621-624.

Aubin-Horth N, Bourque JF, Daigle G, Hedger R, Dodson JJ (2006). Longitudinal gradients in threshold sizes for alternative male life history tactics in a population of Atlantic salmon (Salmo salar). Can J Fish Aquat Sci 63: 2067-2075.

Bagatell C, Rasch T, Johnson C (1980). A review of the experiments with the 1970 and 1971 brood coho salmon (Oncorhynchus kisutch) from thirteen Washington Department of Fisheries hatcheries. Washington Department of Fisheries: Olympia, WA, Progress Report no. 94.

Bagatell C, Rasch T, Johnson C (1981a). A review of the Experiments with the 1971 Brood Summer/Fall Chinook Salmon (Oncorhynchus Tshawytscha) Released From Washington Department of Fisheries Hatcheries. Washington Department of Fisheries: Olympia, WA, Progress Report no. 139.

Bagatell C, Rasch T, Johnson C (1981b). A review of the 1972 brood coho salmon (Oncorhynchus kisutch) experiments from Puget Sound and coastal area Washington Department of Fisheries hatcheries. Washington Department of Fisheries: Olympia, WA, Progress Report no. 134.

Bagatell C, Rasch T, Johnson C (1981c). A review of the 1973 brood coho salmon (Oncorhynchus kisutch) coded-wire micro-tagging experiments in Puget Sound, coastal and Columbia River areas by the
Washington Department of Fisheries. Washington Department of Fisheries: Olympia, WA. Progress Report no. 127.

Bakke TA, Harris PD (1998). Diseases and parasites in wild Atlantic salmon (Salmo salar) populations. Can J Fish Aquat Sci 55: 247-266.

Bartel R, Ikonen E, Auvinen H (2001). Differences in migration pattern and growth of Polish and Finnish sea trout (Salmo trutta L) released in the same areas. Arch Pol Fish 9: 105-122.

Beacham TD, Murray CB (1986). Comparative developmental biology of chum salmon (Oncorhynchus keta) from the Fraser River, British Columbia. Can J Fish Aquat Sci 43: 252-262.

Beacham TD, Murray CB (1989). Variation in developmental biology of sockeye salmon (Oncorhynchus nerka) and chinook salmon (Oncorhynchus tshawytscha) in British Columbia. Can J Zool 67: 2081-2089.

Beaumont MA, Balding DJ (2004). Identifying adaptive genetic divergence among populations from genome scans. Mol Ecol 13: 969-980.

Behnke RJ (1972). The systematics of salmonids in recently glaciated lakes. J Fish Res Bd Can 29: 639-671.

Bernatchez L (2004). Ecological theory of adaptive radiation: an empirical assessment from Coregonine fishes (Salmoniformes). In: Hendry AP, Stearns SC (eds). Evolution illuminated: Salmon and their Relatives. Oxford University press: Oxford, pp 175-207.

Bernatchez L, Renaut S, Whiteley AR, Campbell D, Derôme N, Jeukens J et al. (2010). On the origin of species: Insights from the ecological genomics of whitefish. Phil Trans $R$ Soc Lond 365: 1783-1800.

Bonin A, Bernatchez L (2009). Challenges in assessing adaptive genetic diversity: Overview of methods and empirical illustrations. In: Bertorelle G, Bruford MW, Chemini C, Hauffe HC, Vernesi C (eds). Population Genetics for Animal Conservation. Cambridge University Press: Cambridge, UK, pp 123-147.

Bower SM, Withler RE, Riddell BE (1995). Genetic variation in resistance to the hemoflagellate Cryptobia salmositica in coho and sockeye salmon. J Aquat Anim Health 7: 185-194.

Bradshaw AD (1965). Evolutionary significance of phenotypic plasticity in plants. Adv Genet 13: 115-155.

Brannon EL, Hershberger WK (1984). Elwha River fall chinook salmon. In: Walton JM, Houston DB (eds). Proceedings of the Olympic wild fish conference. Peninsula College: Port Angeles: Washington, USA, pp 169-172.

Buchanan DV, Sanders JE, Zinn JL, Fryer JL (1983). Relative susceptibility of four strains of summer steelhead to infection by Ceratomyxa shasta. Trans Am Fish Soc 112: 541-543.

Campbell D, Bernatchez L (2004). Genomic scan using AFLP markers as a means to assess the role of directional selection in the divergence of sympatric whitefish ecotypes. Mol Biol Evol 21: 945-956.

Campos JL, Posada D, Moran P (2006). Genetic variation at MHC, mitochondrial and microsatellite loci in isolated populations of Brown trout (Salmo trutta). Conserv Genet 7: 515-530.

Carlson SM, Quinn TP, Hendry AP (2011). Eco-evolutionary dynamics of salmonids. Heredity 106: 438-447.

Carlson SM, Seamons TR (2008). A review of quantitative genetic components of fitness in salmonids: implications for adaptation to future change. Evol Appl 1: 222-238.

Caroffino DC, Miller LM, Kapuscinski AR, Ostazeski JJ (2008). Stocking success of local-origin fry and impact of hatchery ancestry: monitoring a new steelhead (Oncorhynchus mykiss) stocking program in a Minnesota tributary to Lake Superior. Can J Fish Aquat Sci 65: 309-318.

Conover DO, Schultz ET (1995). Phenotypic similarity and the evolutionary significance of countergradient variation. Trends Ecol Evol 10: 248-252.

Consuegra S, Garcia de Leaniz C (2008). MHC-mediated mate choice increases parasite resistance in salmon. Proc $R$ Soc Lond Biol Sci 275: 1297-1403. 
Consuegra S, Megens HJ, Schascl H, Leon K, Jordan WC (2005). Rapid evolution of the MH I class locus results in different allelic compositions in recently diverged populations of Atlantic salmon. Mol Biol Evol 22: 1095-1106.

Coughlan J, McGinnity P, O'Farrell B, Dillane E, Diserud O, de Eyto E et al. (2006). Temporal variation in an immune response gene (MHC I) in anadromous Salmo trutta in an Irish river before and during aquaculture activities. ICES J Mar Sci 63: 1248-1255.

Correia L, Yeaman S, Whitlock MC (2010). Local adaptation does not always predict high mating success. J Evol Biol 23: 875-878.

Craig JK, Foote CJ (2001). Countergradient variation and sexual sex color: phenotypic convergence promotes genetic divergence in carotenoid use between anadromous and nonanadromous morphs of sockeye salmon (Oncorhynchus nerka). Evolution 55: 380-391.

Crozier LG, Hendry AP, Lawson PW et al. (2008). Potential responses to climate change in organisms with complex life histories: evolution and plasticity in Pacific salmon. Evol Appl 1: $252-270$.

Dann TH, Smoker WW (2010). Outbreeding depression after two generations of hybridizing Southeast Alasks Coho salmon populations. Trans Am Fish Soc 139: 1292-1305.

Derome N, Duchesne P, Bernatchez L (2006). Parallelism in gene transcription among sympatric lake whitefish ecotypes (Coregonus clupeaformis Mitchill). Mol Ecol 15: 1239-1250.

DeWoody JA, Avise JC (2000). Microsatellite variation in marine, freshwater, and anadromous fishes compared with other animals. J Fish Biol 56: 461-473.

Dionne M, Caron F, Dodson JJ, Bernatchez L (2008). Landscape genetics and hierarchical genetic structure in Atlantic salmon: the interaction of gene flow and local adaptation. Mol Ecol 17: 2382-2396.

Dionne M, Miller KM, Dodson JJ, Bernatchez L (2009). MHC standing genetic variation and pathogen resistance in wild Atlantic salmon. Phil Trans R Soc B-Biol Sci 364: 1555-1565.

Dionne M, Miller KM, Dodson JJ, Caron F, Bernatchez L (2007). Clinal variation in mhc diversity with temperature: Evidence for the role of host-pathogen interaction on local adaptation in Atlantic salmon. Evolution 61: 2154-2164.

Donaghy MJ, Verspoor E (1997). Egg survival and timing to hatch in two Scottish Atlantic salmon stocks. J Fish Biol 51: 211-214.

Einum S, Fleming IA 2000. Selection against late emergence and small offspring in Atlantic salmon (Salmo salar, L). Evolution 54: 628-639.

Endler JA (1986). Natural Selection in the Wild,. Princeton University Press: Cambridge, MA.

Evans ML, Neff BD (2009). Major histocompatibility complex heterozygote advantage and widespread bacterial infections in populations of Chinook salmon (Oncorhynchus tshawytscha). Mol Ecol 18: 4716-4729.

Evans ML, Neff BD, Heath DD (2010). Quantitative genetic and translocation experiments reveal genotype-by-environment effects on juvenile life-history traits in two populations of Chinook salmon (Oncorhynchus tshawytscha). J Evol Biol 23: 687-698.

Federenko AY, Shepherd BG (1986). Review of salmon transplant procedures and suggested transplant guidelines. Can Tech Rep Fish Aquat Sci 1479: 144 pages.

Ford MJ (2000). Effects of natural selection on patterns of DNA sequence variation at the transferrin, somatolactin, and p53 genes within and among chinook salmon (Oncorhynchus tshawytscha) populations. Mol Ecol 9: 843-855.

Fraser DJ, Bernatchez L (2005). Adaptive migratory divergence among sympatric brook charr populations. Evolution 59: 611-624.

Fraser DJ, Cook AM, Eddington JD, Bentzen P, Hutchings JA (2008). Mixed evidence for reduced local adaptation in wild salmon resulting from interbreeding with escaped farmed salmon: complexities in hybrid fitness. Evol Appl 1: 501-512.
Fraser DJ (2008). How well can captive breeding programs conserve biodiversity? A review of salmonids. Evol Appl 1: 535-586.

Fraser DJ, Houde AS, Debes PV, O'Reilly PT, Eddington JD, Hutchings JA (2010). Consequences of farmed-wild hybridization across divergent wild populations and multiple traits in salmon. Ecol Appl 20: 935-953.

Fuss H, Rasch T (1981). A review of the 1974 brood coho salmon (Oncorhynchus kisutch) experiments from Puget Sound and Coastal Washington Department of Fisheries hatcheries. Washington Department of Fisheries: Olympia, WA, Progress Report no. 147.

Fuss H, Rasch T, Johnson C (1981). A review of the experiments with the 1972 brood chinook salmon (Oncorhynchus tshawytscha) released from eighteen Washington Department of Fisheries hatcheries. Washington Department of Fisheries: Olympia, WA, Progress Report no. 143.

Garcia de Leaniz C, Fleming IA, Einum S, Verspoor E, Jordan WC, Consuegra $S$ et al. (2007). A critical review of adaptive genetic variation in Atlantic salmon: implications for conservation. Biol Rev 82: 173-211.

Garcia de Leaniz C, Verspoor E, Hawkins AD (1989). Genetic determination of the contribution of stocked and wild Atlantic salmon, Salmo salar L., to the angling fisheries in two Spanish rivers. J Fish Biol 35: 261-270.

Garrigan D, Hedrick PW (2003). Perspective: Detecting adaptive molecular polymorphism: Lessons from the MHC. Evolution 57: 1707-1722.

Giger T, Excoffier L, Amstutz U, Day PJ, Champigneulle A, Hansen MM et al. (2008). Population transcriptomics of lifehistory variation in the genus Salmo. Mol Ecol 17: 3095-2108.

Giger T, Excoffier L, Day PJR, Champigneulle A, Hansen MM, Powell $\mathrm{R}$ et al. (2006). Life history shapes gene expression in salmonids. Curr Biol 16: R281-R282.

Gislason D, Ferguson M, Skulason S, Snorrason SS (1999). Rapid and coupled phenotypic and genetic divergence in Icelandic Arctic char (Salvelinus alpinus). Can J Fish Aquat Sci 56: 2229-2234.

Goetz FW, Rosauer D, Sitar S, Goetz G, Simchick C, Roberts S et al. (2010). A genetic basis for the phenotypic differentiation between siscowet and lean lake trout (Salvelinus namaycush). Mol Ecol 19: 176-196.

Gould SJ, Lewontin RC (1979). The spandrels of San Marco and the Panglossian paradigm: a critique of the adaptationist programme. Proc $R$ Soc Lond B Biol Sci 205: 581-598.

Green DM (2005). Designatable units for status assessments of endangered species. Conserv Biol 19: 813-820.

Hancock MJ, Marshall DE (1985). Catalogue of salmon streams and spawning escapements of Statistical area 14, ComoxParksville. Can Data Rep Fish Aquat Sci 504: 134 pp.

Hansen MM, Meier K, Mensberg KL (2010). Identifying footprints of selection in stocked brown trout populations: a spatio-temporal approach. Mol Ecol 19: 1787-1800.

Hansen MM, Skaala O, Jensen LF, Bekkevold D, Mensberg KLD (2007). Gene flow, effective population size and selection at major histocompatibility complex genes: brown trout in the Hardanger Fjord, Norway. Mol Ecol 16: 1413-1425.

Hayes B, Laerdahl JK, Lien S, Moen T, Berg P, Hindar K et al. (2007). An extensive resource of single nucleotide polymorphism markers associated with Atlantic salmon (Salmo salar) expressed sequences. Aquaculture 262: 82-90.

Heath DD, Shrimpton JM, Hepburn RI, Jamieson SK, Brode SK, Docker MF (2006). Population structure and divergence using microsatellite and gene locus markers in Chinook salmon (Oncorhynchus tshawytscha) populations. Can J Fish Aquat Sci 63: 1370-1383.

Haugen TO (2000). Growth and survival effects on maturation pattern in populations of grayling with recent common ancestors. Oikos 90: 107-118.

Haugen TO, Aass P, Stenseth NC, Vøllestad A (2008). Changes in selection and evolutionary responses in migratory brown trout following the construction of a fish ladder. Evol Appl 1: 319-335. 
Haugen TO, Vollestad LA (2000). Population differences in early-life history traits in grayling. J Evol Biol 13: 897-905.

Healey MC (1983). Coastwide distribution and ocean migration patterns of stream- and ocean-type Chinook salmon, Oncorhynchus tshawytscha. Can Field Nat 97: 427-433.

Hemmingsen AR, Holt RA, Ewing RD, McIntyre JD (1986). Susceptibility of progeny from crosses among three stocks of coho salmon to infection by Ceratomyxa shasta. Trans Am Fish Soc 115: 492-495.

Hendry AP (2001). Adaptive divergence and the evolution of reproductive isolation in the wild: an empirical demonstration using introduced sockeye salmon. Genetica 112: 515-534.

Hendry AP (2002). Qst $>=<$ Fst? Trends Ecol Evol 17: 502.

Hendry AP, Day T (2005). Population structure attributable to reproductive time: isolation by time and adaptation by time. Mol Ecol 14: 901-916.

Hendry AP, Hensleigh JE, Reisenbichler RR (1998). Incubation temperature, developmental biology and the divergence of sockeye salmon within Lake Washington. Can J Fish Aquat Sci 55: 1387-1394.

Hendry AP, Letcher BH, Gries G (2003). Estimating natural selection acting on stream-dwelling Atlantic salmon: implications for the restoration of extirpated populations. Conserv Biol 17: 795-805.

Hendry AP, Stearns SC (2004). Evolution illuminated: salmonids and their relatives. Oxford University Press: New York, NY.

Hendry AP, Wenburg JK, Bentzen P, Volk EC, Quinn TP (2000). Rapid evolution of reproductive isolation in the wild: evidence from introduced salmon. Science 290. 516-518.

Hereford J (2009). A quantitative survey of local adaptation and fitness trade offs. Am Natural 173: 579-588.

Houde ALS, Fraser DJ, O'Reilly PT, Hutchings JA (2010). Relative risks of inbreeding and outbreeding depression in the wild in endangered salmon. Evol Appl (submitted).

Hutchings JA (2011). Old wine in new bottles: reaction norms in salmonid fishes. Heredity 106: 421-437.

Hutchings JA, Fraser DJ (2008). The nature of fisheries and farming-induced evolution. Mol Ecol 17: 294-313.

Jensen LF, Hansen MM, Mensberg KL, Loeschcke V (2008b). Spatially and temporally fluctuating selection at non-MHC immune genes: evidence from TAP polymorphism in populations of brown trout (Salmo trutta L. Heredity 100: 79-91.

Jensen LF, Hansen MM, Pertoldi C, Holdensgaard G, Mensberg KL, Loeschcke V et al. (2008a). Local adaptation in brown trout early life-history traits: implications for climate change adaptability. Proc R Soc Lond B Biol Sci 275: 2859-2868.

Jessop BM (1986). Atlantic salmon (Salmo salar) of the Big Salmon River, New Brunswick. Can Tech Rep Fish Aquat Sci 1415, 50p.

Jonasson J (1996). Selection experiments on Atlantic salmon ranching. II. Variation among release sites and strains for return rate, body weight and ratio of grilse to total return. Aquaculture 144: 277-294.

Joost S, Bonin A, Bruford MW, Després L, Conord C, Erhardt G et al. (2007). A spatial analysis method (SAM) to detect candidate loci for selection: towards a landscape genomics approach to adaptation. Mol Ecol 16: 3955-3969.

Jordan WC, Verspoor E, Youngson AF (2005). The effect of natural selection on estimates of genetic divergence among populations of the Atlantic salmon. J Fish Biol 51: 546-560.

Jordan WC, Youngson AF (1991). Genetic protein variation and natural selection in Atlantic salmon (Salmo salar) parr. J Fish Biol 39(Suppl A): 185-192.

Kallio-Nyberg I, Koljonen ML, Saloniemi I (2000). Effect of maternal and paternal line on spatial and temporal marine distribution in Atlantic salmon. Anim Behav 60: 377-384.

Kavanagh KD, Haugen TO, Gregersen F, Jernvall J, Vollestad AL (2010). Contemporary temperature-driven divergence in a Nordic freshwater fish under conditions commonly thought to hinder adaptation. BMC Evol Biol 10: 350.
Kawecki TJ, Ebert D (2004). Conceptual issues in local adaptation. Ecol Lett 7: 1225-1241.

Kelso BW, Northcote TG, Wehrhahn CF (1981). Genetic and environmental aspects of the response to water current by rainbow trout (Salmo gairdneri) originating from inlet and outlet streams of two lakes. Can J Zool 59: 2177-2185.

Kinnison MT, Unwin M, Hendry AP, Quinn TP (2001). Migratory costs and the evolution of egg size and number in introduced and indigenous salmon populations. Evolution 55: 1656-1667.

Kinnison MT, Unwin MJ, Quinn TP (2008). Eco-evolutionary versus habitat contribution to invasion: experimental evaluation in the wild. Mol Ecol 17: 405-414.

Koskinen MT, Haugen TO, Primmer CR (2002). Contemporary fisherian life-history evolution in small salmonid populations. Nature 419: 826-830.

Kreeger K (1995). Differences in the onset of salinity tolerance between juvenile Chinook salmon from two coastal Oregon river systems. Can J Fish Aquat Sci 52: 623-630.

Landry C, Bernatchez L (2001). Comparative analysis of population structure across environments and geographical scales at major histocompatibility complex and microsatellite loci in Atlantic salmon (Salmo salar). Mol Ecol 10: 2525-2539.

Larsen PF, Nielsen EE, Koed A, Thomsen DS, Olsvik PA, Loeschcke V (2008). Interpopulation differences in expression of candidate genes for salinity tolerance in winter migrating anadromous brown trout (Salmo trutta L). BMC Genetics 9: 12.

Leimu R, Fischer M (2008). A meta-analysis of local adaptation in plants. PLOS One 3: e4010.

Levins R (1968). Evolution in changing environments: some theoretical predictions. Princeton University Press: Princeton, NJ.

Light RJ, Pillemer DB (1984). Summing Up: The Science of Reviewing Research,. Harvard University Press: Cambridge, MA.

Lipsey MW, Wilson DB (2001). Practical Meta-Analysis,. Applied Social Research Methods Series. Sage Publications: Thousand Oaks, CA.

Lowrey PL, Takahashi JS (2004). Mammalian circadian biology: Elucidating genome-wide levels of temporal organization. Ann Rev Genomics Hum Genet 5: 407-441.

Lu G, Bernatchez L (1999). Correlated trophic specialization and genetic divergence in sympatric lake whitefish ecotypes (Coregonus clupeaformis): support for the ecological speciation hypothesis. Evolution 53: 1491-1505.

Mayama H, Nomura T, Ohkuma K (1989). Reciprocal transplantation experiment of masu salmon (Oncorhynchus masou) population. 2. Comparison of seaward migrations and adult returns of local stock and transplanted stock of masu salmon. Sci Repts Hokkaido Salmon Hatchery 43: 99-113.

McClelland EE, Naish KA (2007). Comparisons of FST and QST of growth-related traits in two populations of Coho salmon. Trans Am Fish Soc 136: 1276-1284.

McGinnity P, Prodohl P, O'Maoileidigh N, Hynes R, Baker N, Ferguson A et al. (2003). Fitness reduction and potential extinction of wild populations of Atlantic salmon, Salmo salar, as a result of interactions with escaped farm salmon. Proc $R$ Soc B-Biol Sci 270: 2443-2450.

McGinnity P, Prodohl P, O'Maoileidigh N, Hynes R, Cotter S, Baker $\mathrm{N}$ et al. (2004). Differential lifetime success and performance of native and non-native Atlantic salmon examined under common environmental conditions. I Fish Biol 65(Suppl A): 175-187.

Meier K, Hansen MM, Bekkevold D, Skaala Ø, Mensberg K-LD (2011). An assessment of the spatial scale of local adaptation in brown trout (Salmo trutta L.): footprints of selection at microsatellite DNA loci. Heredity 106: 488-499.

Merila J, Crnokrak P (2001). Comparison of genetic differentiation at marker loci and quantitative traits. I Evol Biol 14: 892-893. 
Michel AP, Sim S, Taylor MS, Powell THQ, Nosil P, Feder JL (2010). Widespread genomic divergence during sympatric speciation. Proc Natl Acad Sci USA 107: 9724-9729.

Miller KM, Kaukinen KH, Beacham TD, Withler RE (2001). Geographic heterogeneity in natural selection on an MHC locus in sockeye salmon. Genetica 111: 237-257.

Morita K, Nagasawa T (2010). Latitudinal variation in growth and maturation of masou salmon (Oncorhynchus masu) parr. Can J Fish Aquat Sci 67: 955-965.

Morrissey MB, Ferguson MM (2009). Marker-assisted determination of the relationship between body size and reproductive success and consequences for evaluation of adaptive life histories. Mol Ecol 18: 4330-4340.

Nicieza AG, Reiriz L, Brana F (1994). Variation in digestive performance between geographically disjunct populations of Atlantic salmon - countergradient in passage time and digestion rate. Oecologia 99: 243-251.

Nolte AW, Renaut S, Bernatchez L (2009). Divergence in gene regulation at young life history stages of whitefish (Coregonus sp.) and the emergence of genomic isolation. BMC Evol Biol 9: 59.

Normandeau E, Hutchings JA, Fraser DJ, Bernatchez L (2009). Population- specific gene expression responses to hybridization between farm and wild Atlantic salmon. Evol Appl 2: 489-503.

O'Malley KG, Banks MA (2008). A latitudinal cline in the Chinook salmon (Oncorhynchus tshawytscha) Clock gene: evidence for selection on PolyQ length variants. Proc $R$ Soc B-Biol Sci 275: 2813-2821.

O'Malley KG, Camara MD, Banks MA (2007). Candidate loci reveal genetic differentiation between temporally divergent migratory runs of Chinook salmon (Oncorhynchus tshawytscha). Mol Ecol 16: 4930-4941.

O'Malley KG, Ford MJ, Hard JJ (2010). Clock polymorphism in Pacific salmon: Evidence for variable selection along a latitudinal gradient. Proc R Soc B-Biol Sci (e-pub ahead of print; doi:10.1098/rspb.2010.0762).

Pakkasmaa S, Piironen J (2001). Water velocity shapes juvenile salmonids. Evol Ecol 14: 721-730.

Pavey SA, Nielsen JL, Hamon TR (2010). Recent ecological divergence despite migration in sockeye salmon (Oncorhynchus nerka). Evolution 64: 1773-1783.

Perry GML, Audet C, Bernatchez L (2005). Maternal genetic effects on adaptive divergence between anadromous and resident brook charr during early life-history. J Evol Biol 18: 1348-1361.

Potvin C, Bernatchez L (2001). Lacustrine spatial distribution of landlocked Atlantic salmon populations assessed across generations by multilocus individual assignment and mixed-stock analyses. Mol Ecol 10: 2375-2388.

Quinn TP (2005). The behavior and ecology of Pacific salmon and trout,. University of Washington Press, Seattle, WA, USA.

Quinn TP, Hodson S, Flynn L, Hilborn R, Rogers DE (2007). Directional selection by fisheries and the timing of sockeye salmon (Oncorhynchus nerka) migrations. Ecological Applications 17: 731-739.

Quinn TP, McGinnity P, Cross TF (2006). Long-term declines in body sizes and shifts in run-timing of Atlantic salmon in Ireland. J Fish Biol 68: 1713-1730.

Raleigh RF (1971). Innate control of migrations of salmon and trout fry from natal gravels to rearing areas. Ecology 52: 291-297.

Reisenbichler RR (1988). Relation between distance transferred from natal stream and rcovery rate for hatchery coho salmon. N Am J Fish Mgmt 8: 172-174.

Renaut S, Nolte AW, Bernatchez L (2010). Mining transcriptome sequences towards identifying adaptive Single Nucleotide Polymorphisms in lake whitefish species pairs (Coregonussp). Mol Ecol 19(Suppl 1): 151-131.

Reznick D, Travis J (1996). The empirical study of adaptation in natural populations. In: Rose MR, Lauder GV (eds). Adaptation. Academic Press: New York, pp 243-289.
Ricker WE (1972). Hereditary and environmental factors affecting certain salmonid populations. In: Simon RC, Larkin PA (eds). The stock concept in Pacific salmon,. HR MacMillan Lectures in Fisheries, University of British Columbia, Vancouver, Canada, pp 19-160.

Ricker WE (1981). Changes in the average size and average age of Pacific salmon. Can J Fish Aquat Sci 38: 1636-1656.

Ritter JA (1975). Lower ocean survival rates for hatchery-reared Atlantic salmon (Salmo salar) stocks released in rivers other than their native streams. International Council for the Exploration of the Sea (ICES). CM 1975/M: 26. 10p, Copenhagen, Denmark.

Roberge C, Paez DJ, Rossignol O, Guderley H, Dodson JJ, Bernatchez L (2007). Genome-wide survey of the gene expression response to saprolegniasis in atlantic salmon. Mol Immunology 44: 1374-1383.

Rogers SM, Bernatchez L (2005). Integrating QTL mapping and genome scans towards the characterization of candidate loci under parallel selection in the lake whitefish. Mol Ecol 14: 351-361.

Rogers SM, Bernatchez L (2007). The Genetic architecture of ecological speciation and the association with signatures of selection in natural lake whitefish (Coregonus sp. Salmonidae) species pairs. Mol Biol Evol 24: 1423-1438.

Rogers SM, Gagnon V, Bernatchez L (2002). Genetically based phenotype association for swimming behavior in Lake Whitefish ecotypes (Coregonus clupeaformis Mitchill). Evolution 56: 2322-2329.

Schindler DE, Hilborn R, Chasco B, Boatright CP, Quinn TP, Rogers LA et al. (2010). Population diversity and the portfolio effect in an exploited species. Nature 465: 609-613.

Schluter D (2000). The Ecology of Adaptive Radiations,. Oxford University Press, Oxford, UK.

Schluter D, Marchinko KB, Barrett RDH, Rogers SM (2010). Natural selection and the genetics of adaptation in threespine stickleback. Philo Trans Royal Soc Lond 365: 2479-3486.

Slate J, Gratten J, Beraldi D, Stapley J, Hale M, Pemberton JM (2009). Gene mapping in the wild with SNPs: guidelines and future directions. Genetica 136: 97-107.

Spence BC, Hall JD (2010). Saptiotemporal patterns in migration timing of coho salmon (Oncorhynchus kisutch) smolts in North America. Can J Fish Aquat Sci 67: 1316-1334.

St-Cyr J, Derome N, Bernatchez L (2008). The transcriptomics of life-history trade-offs in whitefish species pairs (Coregonus sp.). Mol Ecol 17: 1850-1870.

Stockwell CA, Hendry AP, Kinnison MT (2003). Contemporary evolution meets conservation biology. Trends Ecol Evol 18: 94-101.

Storz JF (2005). Using genome scans of DNA polymorphism to infer adaptive population divergence. Mol Ecol 14: 671-688.

Svardson G, Fagerstroem A (1982). Adaptive Differences in the Long-distance Migration of Some Trout (Salmo trutta L.) Stocks. Report Institute of Freshwater Research: Drottningholm, Sweden, pp 51-80.

Taylor EB (1991). A review of local adaptation in Salmonidae, with particular reference to Pacific and Atlantic salmon. Aquaculture 98: 185-207.

Taylor EB, Foote CI, Wood CC (1996). Molecular genetic evidence for parallel life-history evolution within a Pacific salmon (sockeye salmon and kokanee, Oncorhynchus nerka). Evolution 50: 401-416.

Taylor EB, Tamkee P, Keeley ER, Parkinson EA (2011). Conservation prioritization in widespread species: the use of genetic and morphological data to assess population distinctiveness in rainbow trout (Oncorhynchus mykiss) from British Columbia, Canada. Evol Appl 4: 100-115.

Tautz D, Ellegren H, Weigel D (2010). Multiple marker parallel tag environmental DNA sequencing reveals a highly complex eukaryotic community in marine anoxic water. Mol Ecol 19(Suppl 1): 1-3. 
Tonteri A, Vasemagi A, Lumme J, Primmer CR (2010). Beyond MHC: signals of elevated selection pressure on Atlantic salmon (Salmo salar) immune-relevant loci. Mol Ecol 19: 1273-1282.

Travisano M, Mongold JA, Bennett AF, Lenski RE (1995). Experimental tests of the roles of adaptation, chance and history in evolution. Science 267: 87-90.

Turner SM, Chaves-Campos J, DeWoody JA (2009). Parental relatedness and major histocompatibility effects on early embryo survivorship in Atlantic salmon. Genetica 137: 99-109.

Tymchuk W, O'Reilly PT, Bittman J, MacDonald D, Schulte P (2010). Conservation genomics of Atlantic salmon: variation in gene expression between and within regions of the Bay of Fundy. Mol Ecol 19: 1842-1859.

Unwin MJ, Kinnison MT, Quinn TP (2003). Genetic control over survival in Pacific salmon (Oncorhynchus spp.): experimental evidence between and within populations of New Zealand chinook salmon (O. tshawytscha). Can J Fish Aquat Sci 60: 1-11.

Utter FM (2004). Population structure, conservation and evolution in salmonids and other widely cultured fishes: some perspectives over six decades. Rev Fish Biol Fish 14: 125-144.

Vaha JP, Erkinaro J, Niemela E, Primmer CR (2007). Life-history and habitat features influence the within-river genetic structure of Atlantic salmon. Mol Ecol 16: 2638-2654.

Vasemagi A, Nilsson J, Primmer CR (2005). Expressed sequence tag-linked microsatellites as a source of gene-associated polymorphisms for detecting signatures of divergent selection in Atlantic salmon (Salmo salar L.). Mol Biol Evol 22: 1067-1076.

Waples RS (1991). Pacific salmon and the definition of "species" under the Endangered Species Act. Mar Fish Rev 53: 11-22.

Waples RS, Teel DJ, Myers JM, Marshall AR (2004). Life history divergence in chinook salmon: historic contingency and parallel evolution. Evolution 58: 386-403.

Weitkamp LC, Wainwright TC, Bryant GJ et al. (1995). Status Review of Coho Salmon in Washington, Oregon and California. NMFS-NWFSC-24: Seattle, WA, USA.

Whiteley AR, Derôme N, Rogers SM, St-Cyr J, Labbe A, Bernatchez L (2008). The phenomics of brain transcriptomes regulating adaptive divergence in lake whitefish species pairs. Genetics 180: 147-164.

Whitlock MC (2008). Evolutionary inference from Qst. Mol Ecol 17: $1885-1896$.

Williams JG, Zabel RW, Waples RS, Hutchings JA, Connor WP (2008). Potential for anthropogenic disturbances to influence evolutionary change in the life history of a threatened salmonid. Evol Appl 1: 271-285.

Withler FC (1982). Transplanting Pacific salmon. Can Tech Rep Fish Aquat Sci 1079: 27 pp.

Wood CC, Foote CJ (1996). Evidence for sympatric genetic divergence of anadromous and nonanadromous morphs of sockeye salmon (Oncorhynchus nerka). Evolution 50: 1265-1279.

Wright S (1931). Evolution in Mendelian populations. Genetics 16: $97-159$.

Supplementary Information accompanies the paper on Heredity website (http://www.nature.com/hdy) 